\title{
Karstic Systems in Eastern Belgium: Remouchamps and Noû Bleû
}

\author{
Alexandre Peeters and Camille Ek
}

\begin{abstract}
Belgium is characterised by a wide variety of rocks, including carbonate formations, which are significantly represented in eastern Belgium. Among those formations, Devonian and Carboniferous carbonates display the most developed karstic features, as illustrated by the two cave systems presented in this chapter. Although both systems are water caves, they differ in many ways. The Remouchamps Cave, developed in the Upper Devonian limestones, is a touristic cave, while the Noû Bleû Cave, developed in the Carboniferous carbonates, is a brand new discovery still under exploration. The two systems are of scientific interest and contain many deposits (speleothems and detrital sediments) providing records of past environmental changes and paleoclimates. Beside the Quaternary dynamics, the present-day dynamics can be highlighted within the karstic basins that encompass the two cave systems. The generation or reactivation of sinkholes and swallow holes is often favoured or triggered by human activity. Furthermore, the two basins offer several good examples of human interaction with karst environments, not only in terms of karstic constraints for humans but also as a resource that must be preserved.
\end{abstract}

\section{Keywords}

Remouchamps Cave • Noû Bleû Cave • Karst dynamics • Speleothems • Sinkholes

\subsection{Introduction}

Wallonia, the southern half of Belgium, is rich in carbonate rocks, amounting to $12 \%$ of the outcrops, but occurring much more widely underground. These carbonate formations are mostly Palaeozoic limestones and dolostones but there are also Palaeozoic calcareous conglomerates and Cretaceous chalks (Boulvain and Pingot 2015; see also Chap. 2).

These carbonate rocks are significantly represented in eastern Belgium (Fig. 8.1). Devonian limestones and

\author{
A. Peeters $(\bowtie)$ \\ Department of Physical Geography and Quaternary, \\ University of Liège, Sart Tilman, B11, 4000 Liège, Belgium \\ e-mail: A.Peeters@ulg.ac.be \\ C. Ek \\ Université de Liège, Liège, Belgium \\ e-mail: camille.ek@ulg.ac.be
}

dolostones include many pure carbonate rocks (more than 90\% calcium and magnesium carbonate). Carboniferous carbonate rocks are also frequently pure. Permian rocks are conglomerates with a calcareous matrix. North of Liège, Cretaceous formations include chalk, with notable karstic features (dolines) but only a few and small caves (see Chap. 11). In the very south of the country (outside the map) there are a few outcrops of Jurassic carbonate rocks, but without notable known caves.

In this chapter two cave systems from the region will be presented in detail. One of them-Remouchamps-is selected because it is large, very popular and includes a $600 \mathrm{~m}$ boat trip; the other one-so-called Noû Bleû-because it is a brand new discovery, still currently in progress (2012-2016). Both caves are the resurgences of important karstic basins, fed by numerous swallow holes. The first of these basins is the Sinkhole Dale, resurging at Remouchamps. This $7 \mathrm{~km}$ long watershed drains an area of $22 \mathrm{~km}^{2}$. 


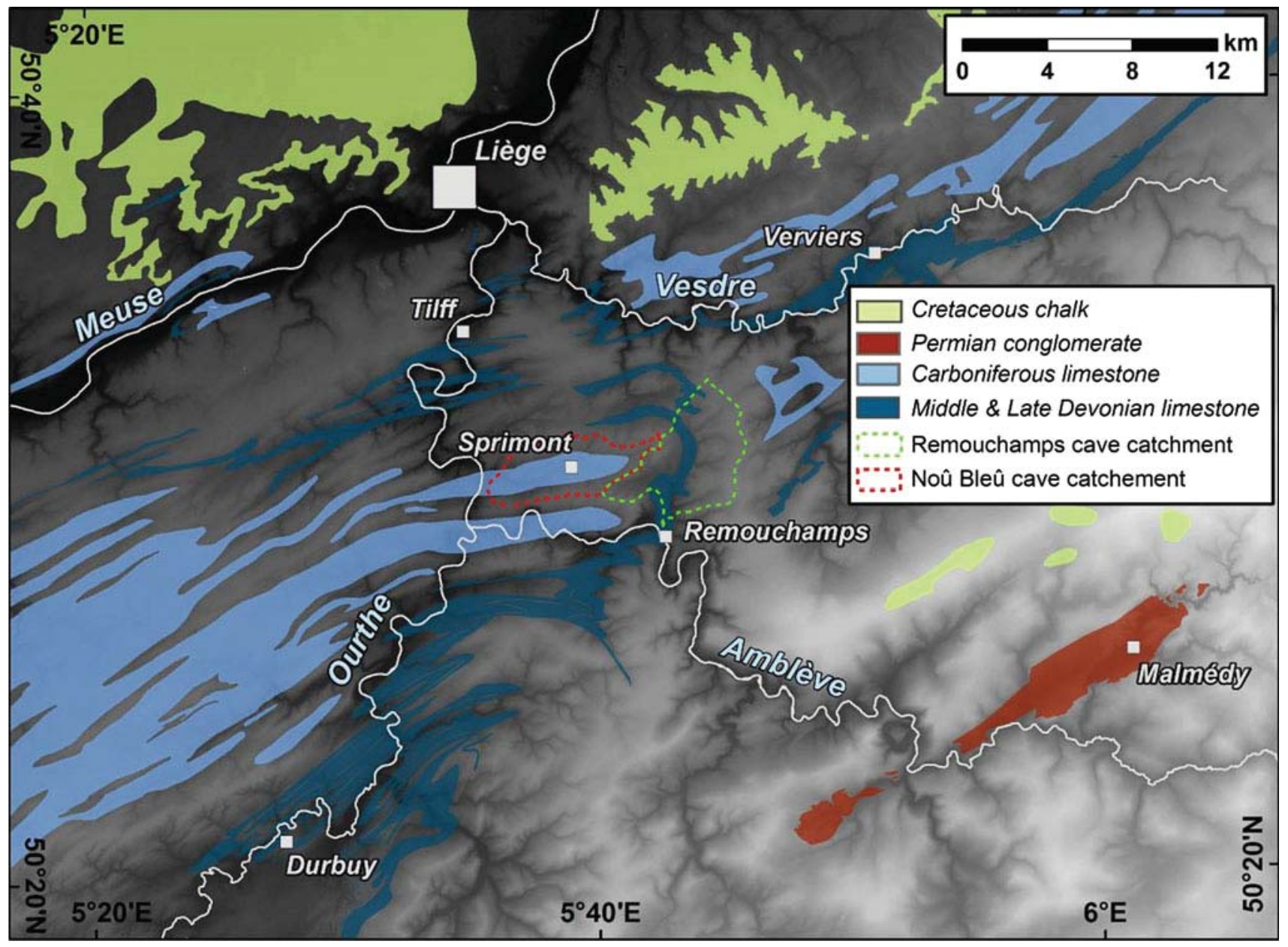

Fig. 8.1 Carbonate formations of eastern Belgium and the two studied catchments: Sinkhole Dale (green dotted line) and Sprimont Syncline (red dotted line)

It is riddled by hundreds of small dolines and swallow holes, including a few which are very spectacular (Fig. 8.2). The second basin is one of a dry valley extending along a syncline which stretches across the Sprimont municipality. It is $8 \mathrm{~km}$ long and collects the water from an area of $18 \mathrm{~km}^{2}$. A water cave was discovered there by a local caving club, the "Club de Recherches Spéléologiques Ourthe-Amblève" (C.R.S.O.A.). This important cave opens in an active quarry, hence some security problems.

\subsection{The Remouchamps Cave and Its Drainage Area}

\subsubsection{The Sinkhole Dale}

$25 \mathrm{~km}$ south of Liège, as the crow flies, the Sinkhole Dale extends N-S in Frasnian (Upper Devonian) limestones. Frasnian limestones have been described in detail by Boulvain et al. (1999). On the eastern side of the valley, they rest on older rocks, mainly shales, sandstones and quartzites. The western flank consists of a thin shaly formation and calcareous sandstones. The limestone strip, here in lowered position and forming a dale, separates the Condroz (west of the depression) from the Ardenne (east of the depression) (Fig. 8.3). The slopes, on both sides, are generally steep and the limestone is deeply entrenched. The bottom displays no talweg.

The small rivulets coming from both sides disappear in small or large swallow holes when reaching the calcareous formation. The surface of the depression displays numerous dolines (sinkholes) and no stream drains the bottom of this dry valley. This leads to disastrous floods when stormy rains occur (Fig. 8.4).

The general dip of the bedding planes is to the west, but secondary folds and numerous faults complicate the geological structure. Nevertheless, most of the rivulets flowing from Ardenne and Condroz run westward-according to the dip_-when sinking underground. Consequently, whereas rivulets from Ardenne continue their course straight to west, 


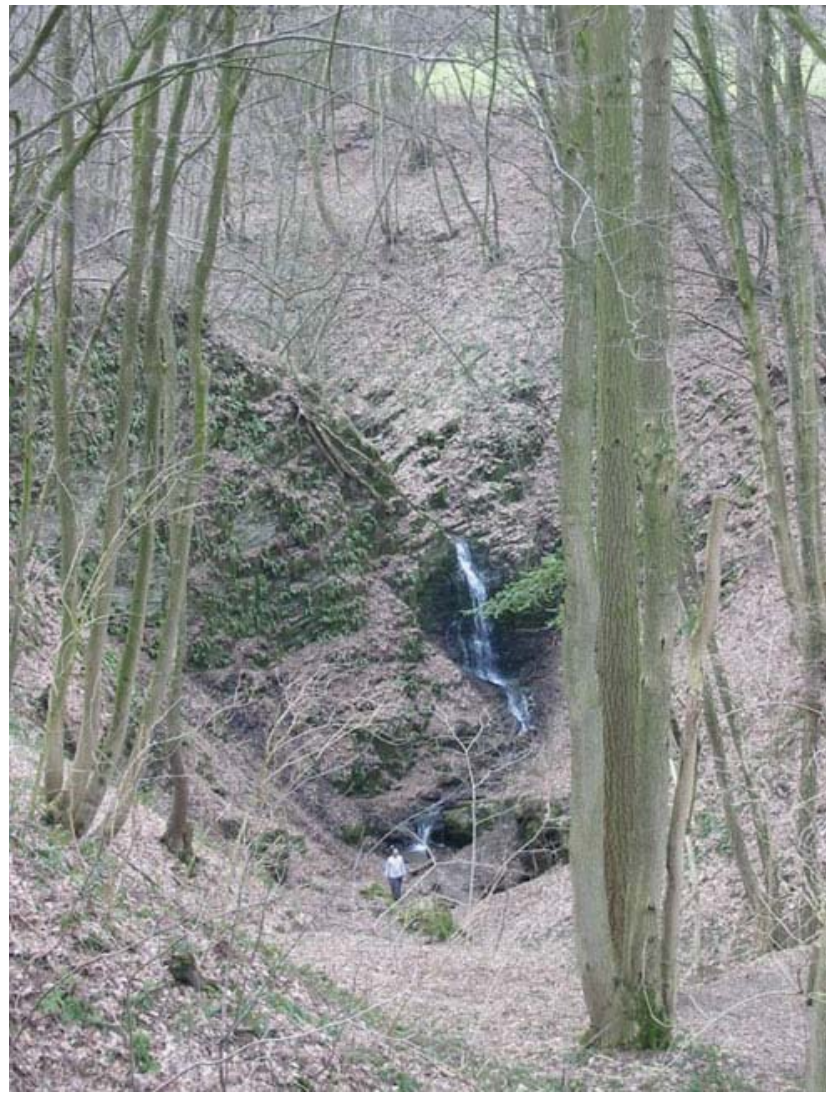

Fig. 8.2 The Grandchamps doline and swallow hole. The doline is about $250 \mathrm{~m}$ long and $26 \mathrm{~m}$ deep. The swallet generally absorbs a few $1 / \mathrm{s}$, sometimes less in summer, but can swallow $400 \mathrm{l} / \mathrm{s}$ and perhaps more in flood conditions

Condroz tributaries make a U-turn and their underground course passes below their surficial way (Fig. 8.5).

\section{Quaternary and present-day dynamics}

During Pleistocene times, periglacial conditions occurred repeatedly, influencing the type and rates of geomorphological processes. Proofs of permafrost were discovered in the Remouchamps Cave $60 \mathrm{~m}$ below the surface (Pissart et al. 1988). Solifluction deposits filled the valley and blocked the caves. Some holes were filled up to the roof, as demonstrated by sandstone pebbles still staying in fissures nearby the roof of some caves, like in the Rouge-Thier swallow hole. Some blind valleys heading to swallow holes were totally filled by deposits coming from the slopes. The periglacial periods were thus characterized by the interruption of karstic processes.

At the end of the last periglacial period, frozen ground was thawing so that the Holocene is characterized by the reactivation of perennial runoff. Nowadays, many caves have been unblocked. Underground flow is reborn. New swallow holes frequently open upstream from the old ones, as will be shown for the Noû Bleû area in the next section.

\subsubsection{The Remouchamps Cave}

\subsubsection{A Large Cave, a Long Boat Trip}

The Remouchamps Cave, a water cave, is drained by a stream which is a tributary of the Amblève River. It is a two level cave: an underground river flows in the lower storey, whereas, about ten meters higher, the upper level is dry (Fig. 8.6a). The total length of all passages is about $3900 \mathrm{~m}$.

The Remouchamps Cave is the resurgence of all the swallow holes riddling the Sinkhole Dale. The underground stream flowing in the cave is deep enough to allow touristic navigation throughout the year, except during heavy floods. The biggest hall of the cave, the Cathedral, is about $60 \mathrm{~m}$ long and $35 \mathrm{~m}$ high (Ek 1995). But the floor of the hall is resting on a 25 -m-thick mass of fallen rocks, so that if the scree was removed the true height of the Cathedral would be about $60 \mathrm{~m}$ (Fig. 8.6b). Tourists visiting the cave first walk along the upper level, go to the Cathedral, and come back by the river, sailing in a small boat. The navigation is about $600 \mathrm{~m}$ long.

\subsubsection{A Complex Geological Structure}

The cave is developed in a single stratigraphical unit of the Frasnian limestones: the Lustin Formation (Coen 1970; Ek 1970b). This $\sim 100$-m-thick formation consists of biostromal limestone with stromatoporoids and corals, and bedded micritic limestones. The shaly Aisemont Formation surmounts the Lustin Formation. These shales clearly appear at the very end of the cave, in the so-called Shale Chamber (shown in red on the geological map of Fig. 8.7).

Below this shaly formation, the Lustin Formation is divided in three parts. The Lower part (formerly F2d) is a thick biostrome, as is also the Upper one (formerly F2h). Between them, the Middle part (formerly F2efg) does not display massive Stromatopora, but many tabular ones and corals. All the beds are pure (>90\%) to generally very pure limestone, except for a few thin argillaceous layers. Thanks to the continuous exposure, the cave map reveals a structural complexity unpredicted by the surface survey. Located at the very eastern end of the Dinant basin, the bedrock dips west. But, as indicated by the structure contours of the map, there are several secondary folds and transverse faults, all Variscan in age (Fig. 8.7). The main structural features are two anticlines, with faulted hinges, separated by a transverse syncline.

The floor of the cave is generally covered by alluvium or fallen blocks, or in some places by artificial embanking, so that geological mapping of the floor is impossible. We have 
Fig. 8.3 Geological map of the Sinkhole Dale. The Frasnian limestone is surrounded by Famennian shales and sandstones to the west and by Middle and Lower Devonian shales and sandstones to the east. Famennian sandstones generally have a calcareous or dolomitic cement (up to $15 \%$ ) and their waters are hard while Lower Devonian sandstones are devoid of carbonate and deliver acidic waters

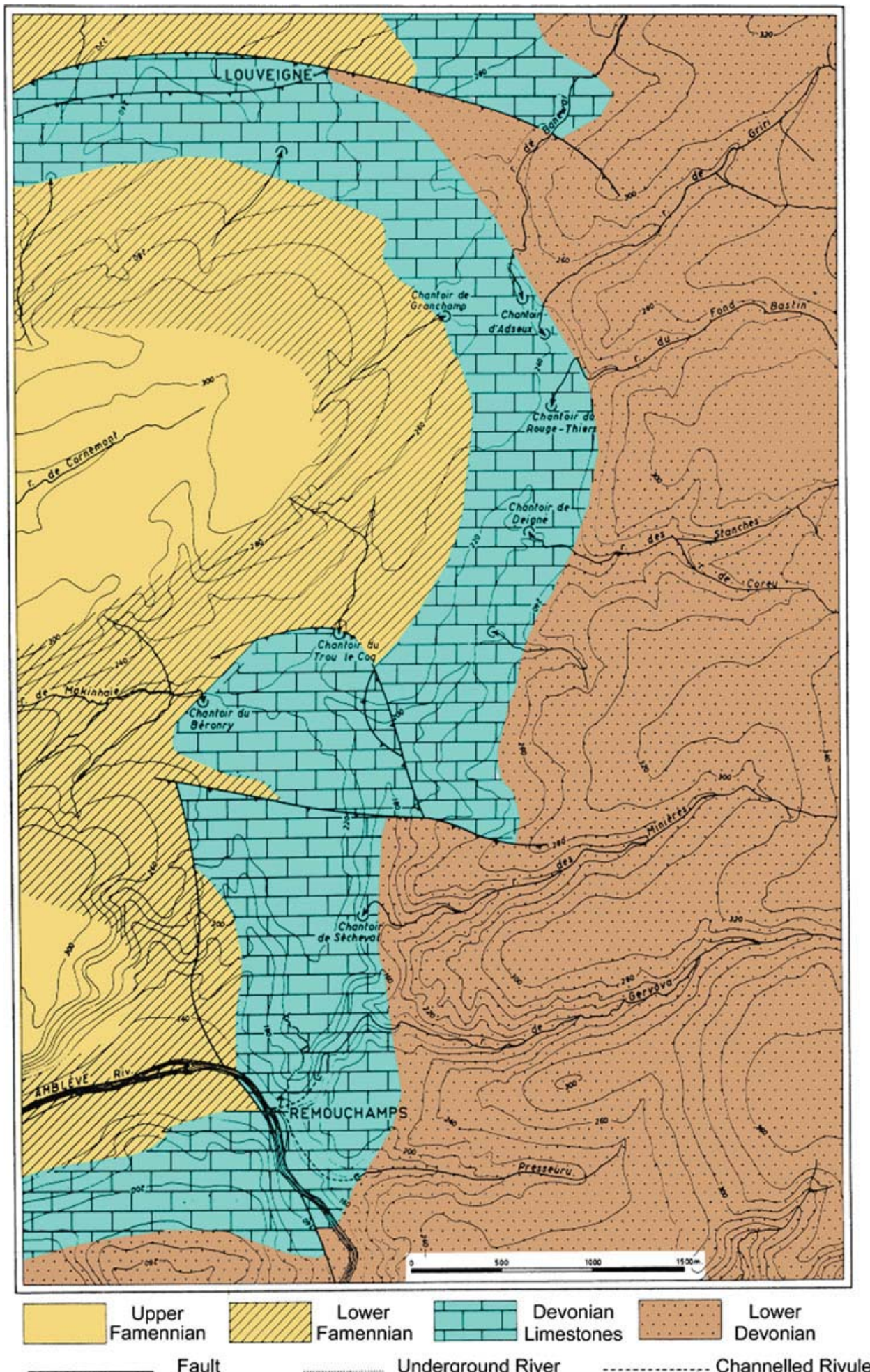

thus used the walls and the roof. As the height of the roof is very variable, the stratigraphic limits look more complicated than they really are. The observed faults are reverse, except for the more northerly - the Faille Cathédrale Nord - which is normal.

\subsubsection{A Very Varied Morphogenesis}

The geological structure has had much influence on the cave morphology. Some beds are more easily dissolved than others, not necessarily because they are purer but, e.g., because of a petrographic structure (porosity, clay 

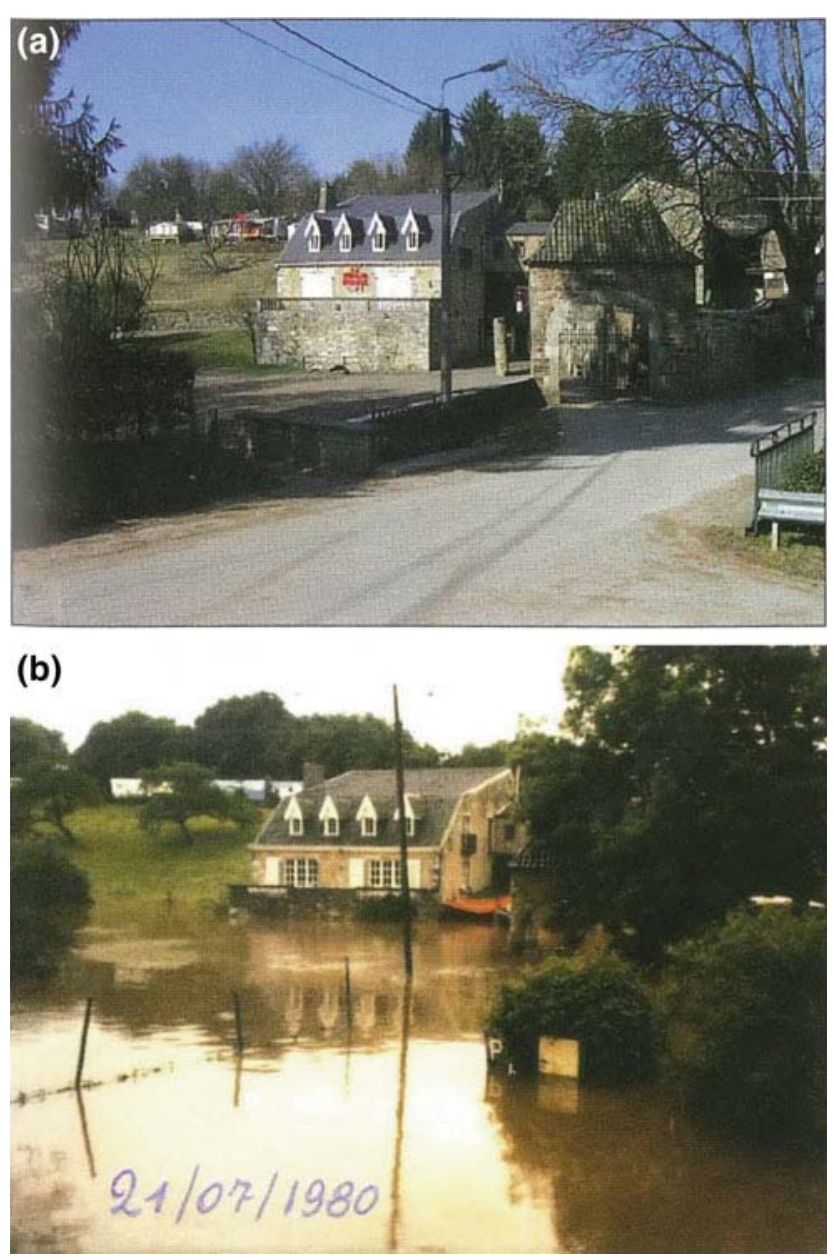

Fig. 8.4 a Trou-du-Moulin doline in low water conditions in 2005 (Photo JC Schyns). b The same in extreme flood conditions in 1980. The ground floor of the house in the background is totally flooded (Photo M Etienne)

distribution) that makes the attack by water easier. Generally, dissolution does not begin in a purer bed but along a more open sedimentary joint.

The dip of the beds had in some places a determining effect on the underground stream, some important sumps having formed where the flow direction was parallel to the direction of the dip (Fig. 8.8). In such a situation, the stream saps the rock and displays a trend to siphon. Joints also may affect water circulation: they provide more favourable routes than the bedding planes because they are frequently more open and cleaner.

The Labyrinth displays an example of a combined influence of joints and beddings planes (Fig. 8.9). All passages of the upper level, in this figure, are in the same bed. The direction of all passages is determined by joints. The current situation (last stage of the figure) shows the river flowing in the lower storey, whereas the upper level, dipping $25 \mathrm{~W}$, displays two large galleries and a lot of narrow passages. Originally (stage 1), the river was flowing through a gallery
(A on Fig. 8.9), where rounded pebbles can still be found. After the intermediate stage 2, the stream moved westward (stage 3). In this situation, it passed through a sump, due to the westward dip of the bed. During dry periods, when there was no flow anymore, some water could remain in the bottom of the sump. And when the main river, the Amblève, eroded its bed and began to flow $10 \mathrm{~m}$ lower, the underground tributary followed this descent by a waterfall through a pit, prepared long ago by dissolution and leading to the developing lower level (B on stage 4). Later on, this lower level developed upstream in the cave, leaving the upper level totally dry.

Though Variscan in age, the faults also affect karstification, favouring important Quaternary breakdowns along their traces. As an example, the biggest hall of the cave corresponds to a normal fault (Cathedral-North Fault), expressing stretching (Ek 1969) (Fig. 8.10).

\subsubsection{Water Action and Breakdowns: A Long Speleogenesis}

The main erosion process responsible for the origin of the present morphology of the cave is certainly concentrated underground flow. The lower level of the cave consists only of the riverbed, making clear that the stream is the agent which carved this whole storey. Most of the passages of the upper level, showing the same morphology, have most probably the same origin.

A fluvial terrace of the Amblève located $\sim 8 \mathrm{~m}$ higher than the present floodplain corresponds to the altitude of the upper level of entrance and of the cave (Ek 1957, 1961; Rixhon and Demoulin 2010). As it does not contain minerals of the 74-90 ka-old Rocourt tephra (Juvigné and Gewelt 1988; Rixhon and Demoulin 2010), this terrace is presumably older than $90 \mathrm{ka}$ and so is probably the age of this level of the cave.

Underground fluvial morphology in the Remouchamps Cave is characterized by large and high erosion notches, large meanders and pebble deposits. These features are lacking at some places of the upper level and, whereas it is sure that a river has run along the whole storey, it is not obvious that each place of the upper level owes its morphology to fluvial action. Other water actions, like diffuse flow giving rise to what Bretz (1942) called roof anastomoses and rock pendants, could as well have carved some passages, which were identified as such in the morphogenetic map of the cave (Fig. 8.10). This map provides sufficient evidence that water was the main agent of the cave morphogenesis, although specific processes varied (pressure pipes, phreatic processes, diffuse flow, underground stream, sumps). Even pits and fissures, when visible, attest enlargement by water action. In narrow passages or where water flows very slowly, dominant action is dissolution. Where flow rate or velocity is high, mechanical action 
NW

SE

CONDROZ

Sinkhole Dale
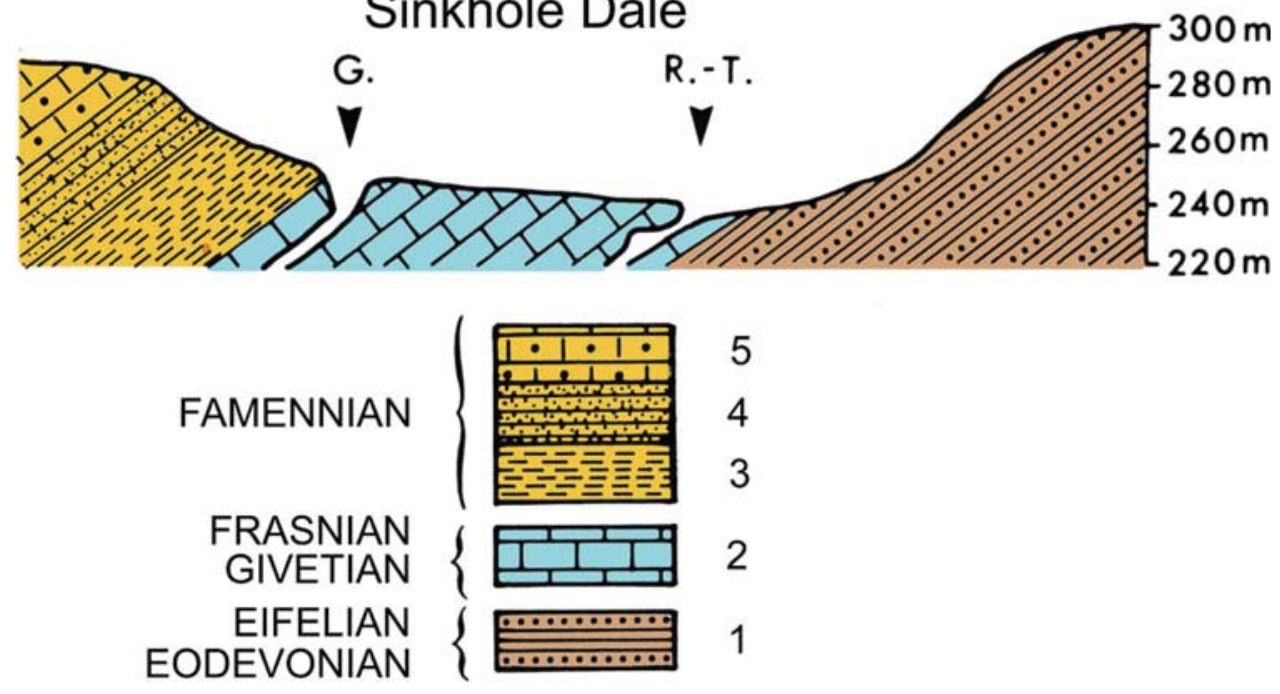

Fig. 8.5 NW-SE cross-section in the Sinkhole Dale (G: Grandchamps swallow hole, see Fig. 8.2; R.T.: Rouge-Thiers swallow hole in the Trou du Moulin doline, see Fig. 8.4). Underground streams run westward. Thus waters of Grandchamps swallow hole run eastward outside and then westward underground

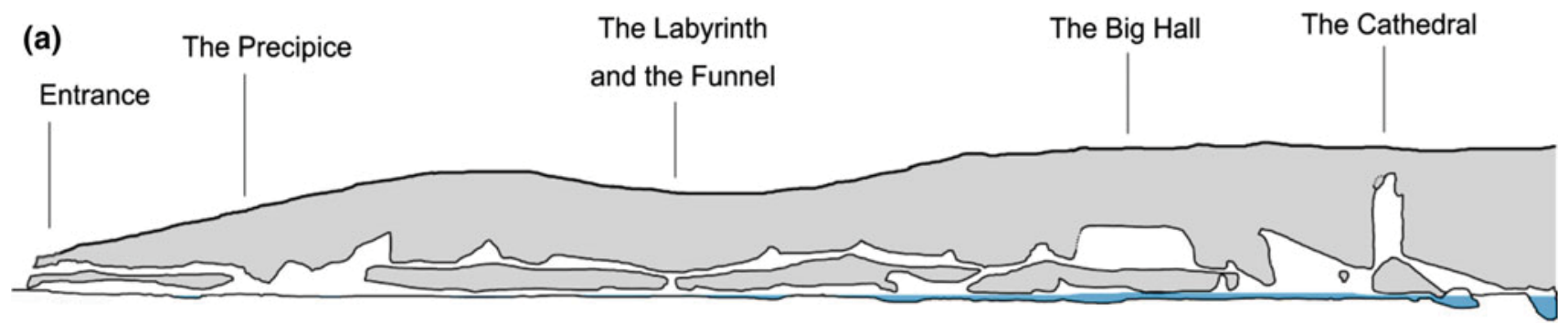

$0 \quad 20 \quad 40 \quad 60 \quad 80100 \mathrm{~m}$

(b)

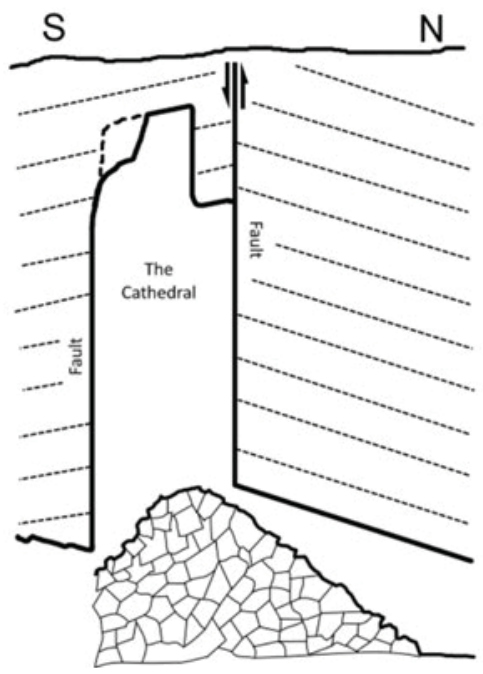

Fig. 8.6 a Longitudinal profile (developed) of the two-storey cave of Remouchamps (heights not exaggerated). b Cross-section of the Cathedral Hall. The roof is less than $8 \mathrm{~m}$ below the surface (modified after Ek 1970b) 
Fig. 8.7 Geological map of Remouchamps Cave. 1 Cave limit. 2 Fault. 3 Structure contour (generalized). F2ij. Aisemont Formation (shale). F2h. Lustin Formation (upper part). F2efg Lustin Formation (middle part). F2d Lustin Formation (lower part) (modified after Ek 1970a)

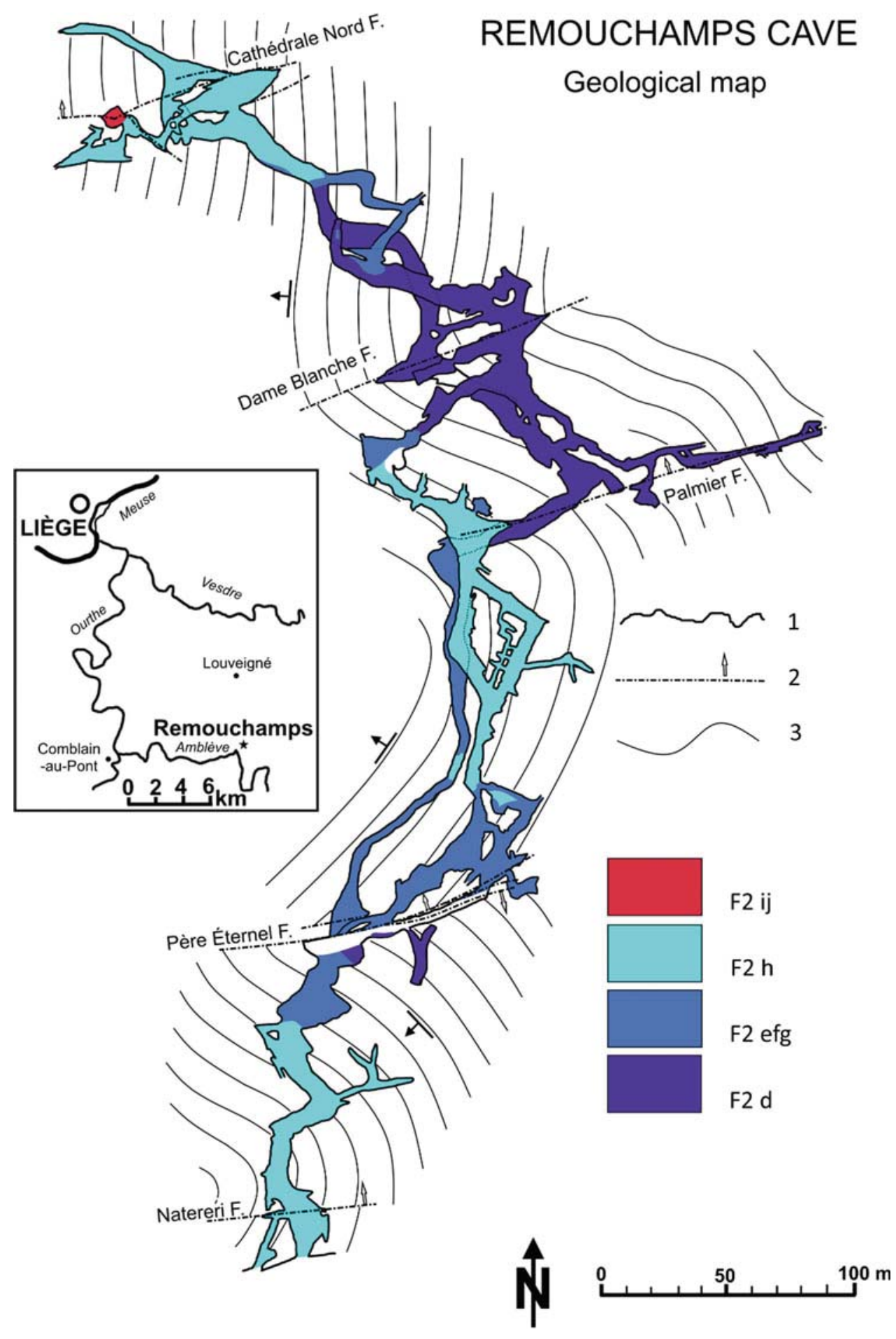

generally becomes predominant. Sumps occur in the riverbed when the stream is not graded (Fig. 8.8). There are three major sumps in the upper level of the cave (Fig. 8.10). Likewise, while the present bed is better graded in the touristic downstream part of the cave, its upstream section is not yet so well graded, with several sumps having been explored by L. Funcken and other divers.

We have noted a few traces of phreatic processes. In a narrow passage of the upper level, there are some boxworks, i.e., networks of thin calcite veins $(1-3 \mathrm{~mm})$ protruding from 


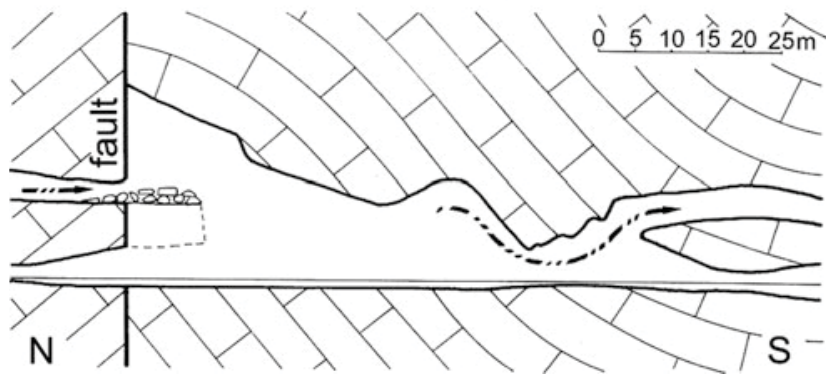

Fig. 8.8 Longitudinal section of a sump in the Remouchamps Cave Dip and stream flow directions are parallel (modified after Ek 1970b)

the wall by several $\mathrm{cm}$ because they are less easily dissolved than the surrounding limestone (Bretz 1942). This kind of very fragile feature cannot withstand a fast flow or a flow including a solid load and it was thus interpreted by Bretz as a sign of standing or very slowly moving water.

Roof and wall breakdowns are a water-independent process involved in the origin of the present morphology of some parts of the cavern (Fig. 8.10). Talus cones are present, and they are generally huge and occur in every large hall. A rockfall needs a preliminary void to occur, so the breakdowns are younger than the water action that created the chambers.

Putting all pieces of evidence together, one can summarise the history of the cave development as follows:

- Fissures and pits (Fig. 8.10) first allowed water to circulate in the bedrock in the very early stages of cavern development.

- Water, descending towards the local base-level, filled voids too scarce for the aquifer recharge; this led to the development of cylindrical pressure pipes, which are marks of a generally saturated aquifer (more incoming water than available voids).

- On the overlying ground surface, swallow holes opened above the Big Hall; although they later filled up and disappeared, they are still evidenced by seismic refraction (Vandenvinne, Girolimetto and Ek, unpublished results) (Fig. 8.11).

- The swallow holes fed a permanent underground rivulet, which progressively became a stream and tended toward a graded profile. This stream was contemporaneous with the $8 \mathrm{~m}$ terrace level; it could not grade perfectly, however, and three sumps remain from that time.

- The underground river of the $8 \mathrm{~m}$ storey occasionally carried huge amounts of exogenous pebbles and eventually blocked some siphons; this is conspicuous in the so-called Hall of the Virgin.

- When, outside, the Amblève River lowered its bed to the present level, the underground stream progressively
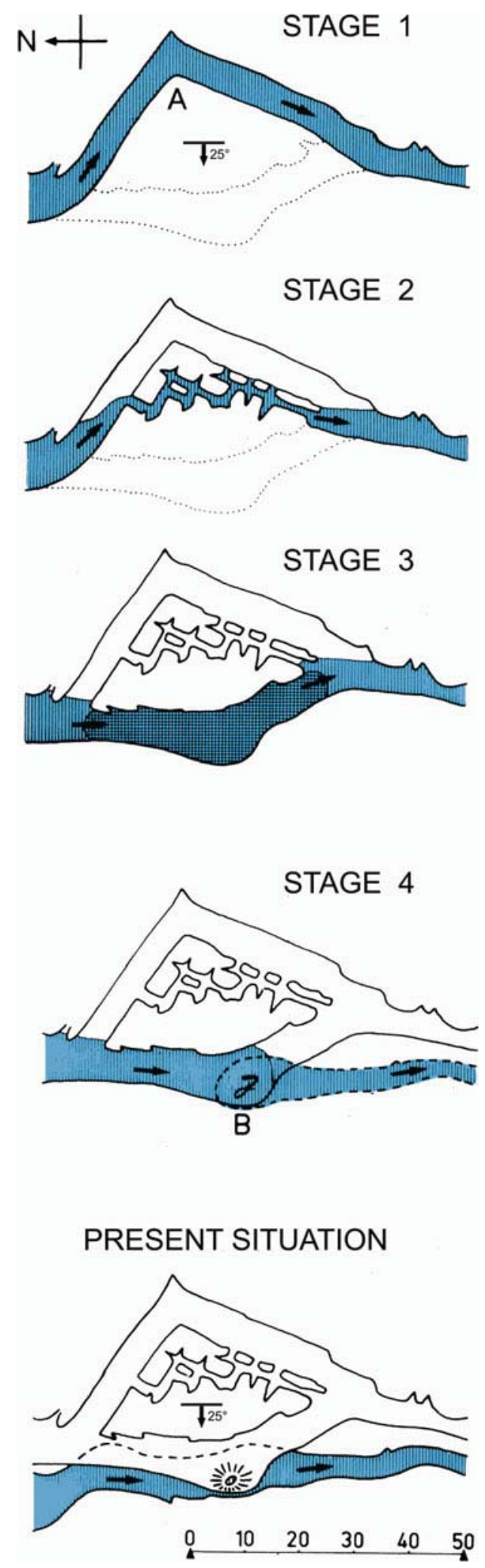

Fig. 8.9 Plan view of the Labyrinth. The present topography of the Labyrinth region of the cave is displayed by the lowest sketch: the river (in blue) is flowing southward straight on along the lowest level whereas all passages of the upper floor, now dry, are determined by two perpendicular sets of joints 
Fig. 8.10 Morphogenetic map of the Remouchamps Cave. 1 Fissure, crack, pit; 2 Pressure pipe; 3 Phreatic processes (very slow move or still water); 4 Diffuse flow, roof anastomoses, unspecified water action; 5 Underground stream; 6 Sump; 7 Breakdown; 8 Anthropogenic digging (simplified after Ek 1969)

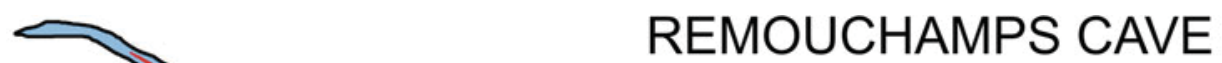
Morphological map

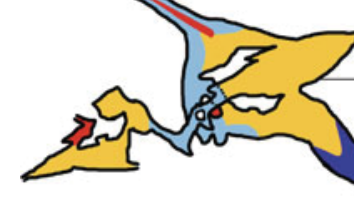

The Cathedral

The Big Hall

The Labyrinth

The Funnel
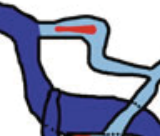

7

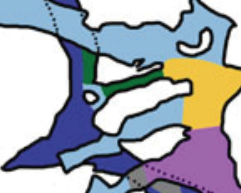

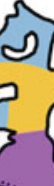
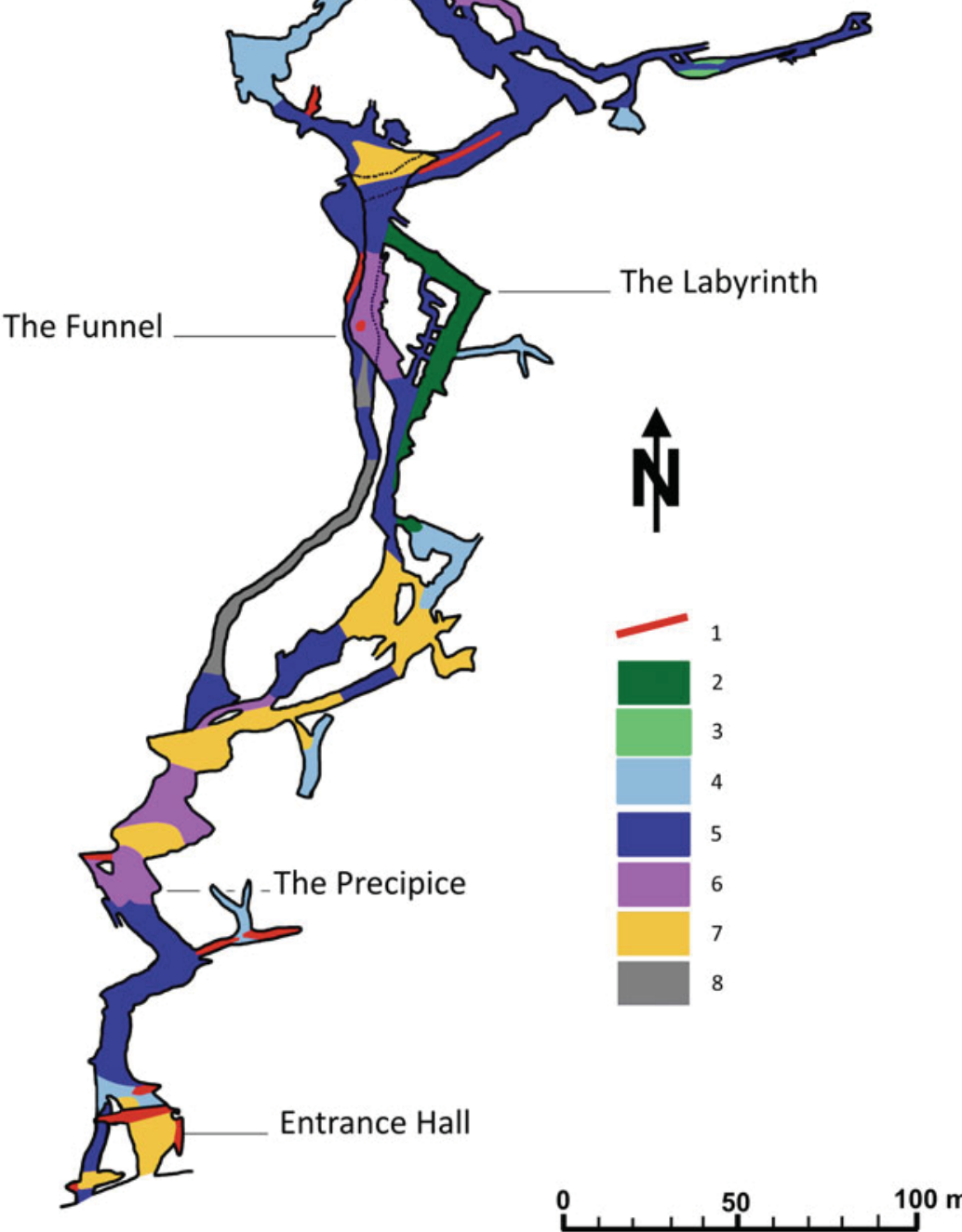

joined its level by successive self-captures, or domestic piracy.

- Several breakdowns occurred and created talus cones in the upper level after it has been partly graded.
U/Th dating of a big broken stalagmite within a huge collapse yielded dates of 126 and $95 \mathrm{ka}$ for the bottom and the top of the speleothem, respectively (Gewelt 1985), (Fig. 8.12). The fall of the stalagmite thus occurred at or 


\section{PROFILE 1}

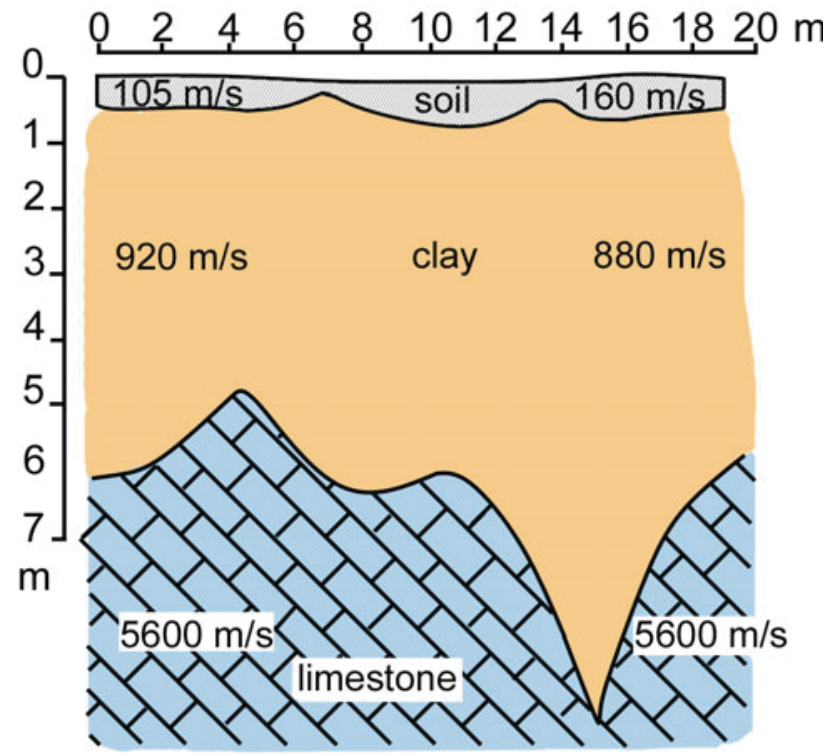

PROFILE 2

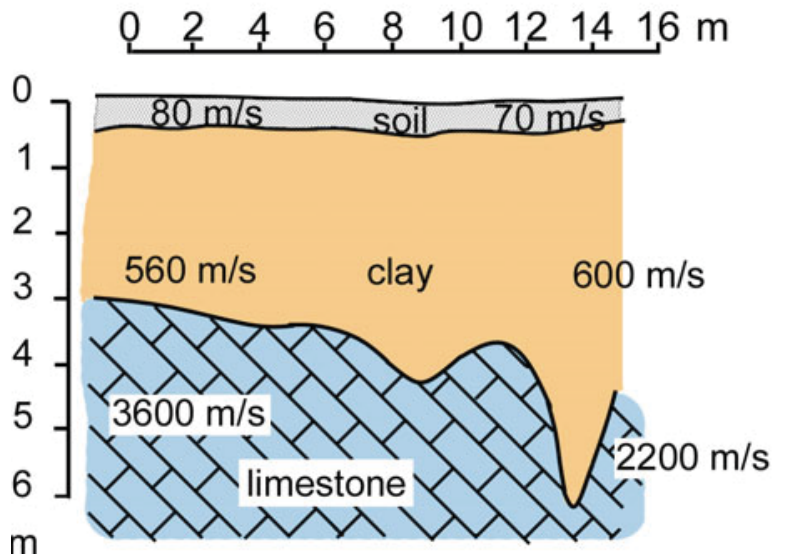

Fig. 8.11 Seismic soundings carried out above the Big Hall (Vandenvinne, Girolimetto and Ek, unpublished results). The analysis of the soundings clearly shows the existence of karstic depressions above the Big Hall, which is the upward terminal of the upper level of the cave. We interpret these depressions as the marks of the swallow holes which once flowed into the cave

after $95 \mathrm{ka}$. Even though the speleothem's growth period coincides with an interglacial, consistent with the idea that karstic processes are favoured by temperate climates and hampered by periglacial conditions, it is likely that the collapse, possibly earthquake-triggered, was the cause of the stopping of the stalagmite's growth. However, no other speleothem broken in that time has been retrieved so far in the cave.

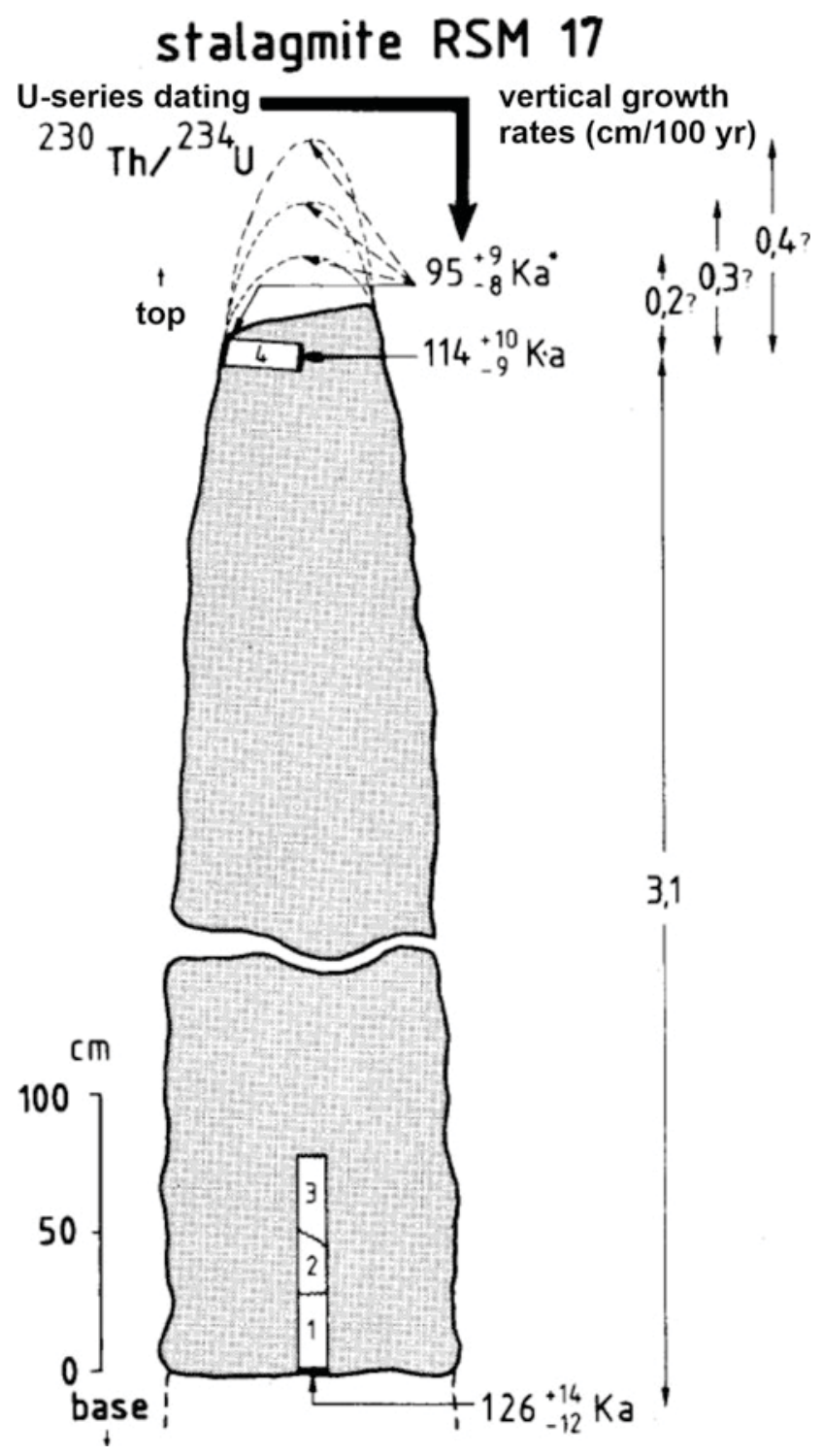

Fig. 8.12 Thorium-Uranium dating of a large broken stalagmite in the Remouchamps Cave (Gewelt 1985). This 4-m-high speleothem began growing 126,000 years ago, and stopped about 95,000 years ago. This corresponds to the Eemian interglacial period. The ending of growth probably was caused by the fall of the stalagmite, swept along by a rockfall

\subsubsection{Man in the Cave}

\subsubsection{The First Inhabitants: Cave Dwellers}

At the very end of the Upper Paleolithic, about 10,000 years ago, a group of hunters of Ahrensburg culture lived temporarily in the cave (Dewez 1974; Ek 1974a, b). They cut and left there a rich flint assemblage, and particularly the so-called Ahrensburg arrow heads (Fig. 8.13a). 
(a)
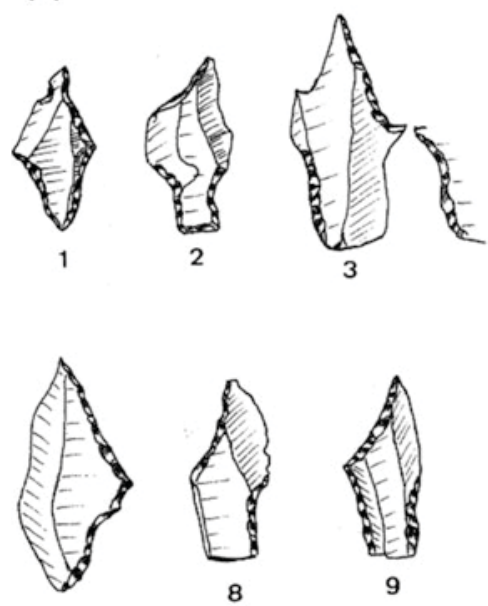

9

7
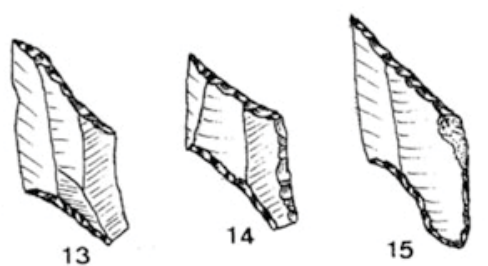

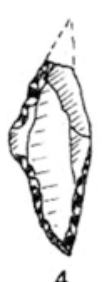

4

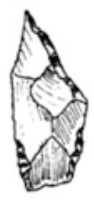

10

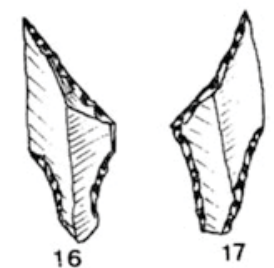

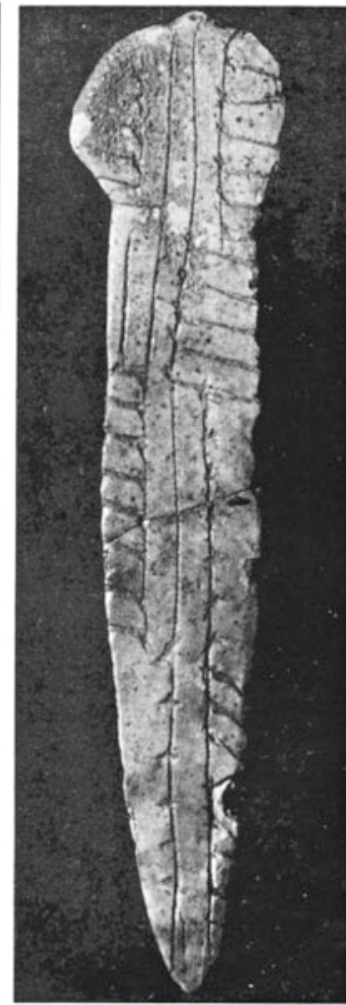

$\overbrace{0} \mathrm{~cm}$

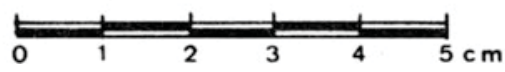

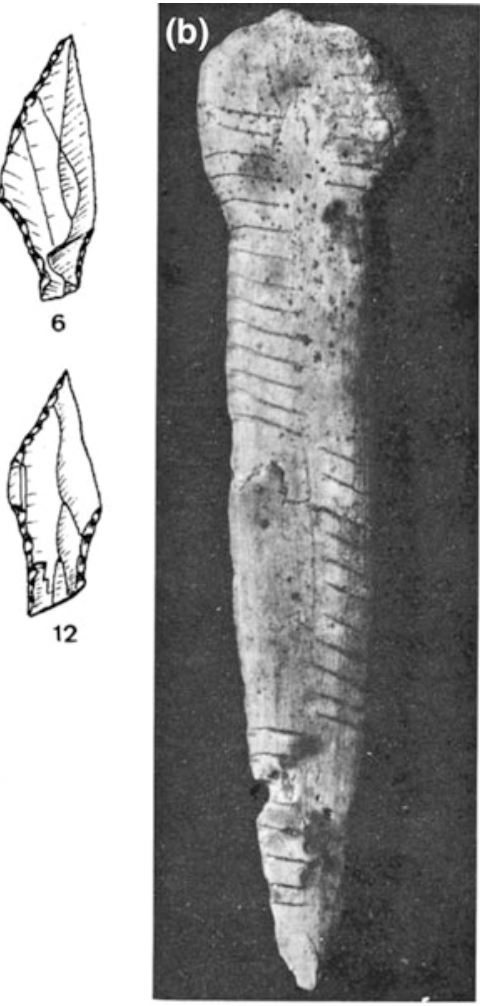

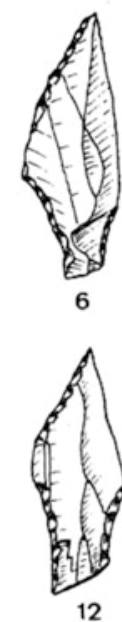

Fig. 8.13 a Ahrensburg arrow heads from the Remouchamps Cave (from Dewez 1974). b 72 mm long polished and engraved bone blade found in the Remouchamps Cave, assigned to the Ahrensburg culture (from Dewez 1974)

They also left perforated Lutetian shells, probably imported from the Paris basin as necklaces, and a polished and curiously striated bone blade, whose purpose could not be defined (Fig. 8.13b). They ate reindeer, Elaphus stag, Megaceros stag, polar fox, horse, wolf and snow grouse. According to an uncalibrated ${ }^{14} \mathrm{C}$ dating of bones of eaten animals, this group of hunters lived and cut flints in the cave by $8430 \pm 170$ years B.C. (Dewez 1974). This yields a calibrated age of 12,196 \pm 324 year cal BP (CalPal_2007_HULU; Weninger and Jöris 2008), which corresponds to the Younger Dryas, the very last cold impulse of the last glaciation. The very small Ahrensburg arrowheads retrieved in the cave suggest that they sometimes hunted very small animals.

No later prehistoric dwellers are known from the cave but Middle Age occupancy is attested by a lot of coins, particularly from the sixteenth century, a period frequently troubled by the wars of religion and during which the coins were probably lost by refugees.

\subsubsection{The Explorers}

In the nineteenth century, the first explorers were students of the Liège University, among them an Englishman, L. Wilmar (Courtois et al. 1969). Taking no heed of the villagers' fears, they went down a $10 \mathrm{~m}$ pit on the 1 st of August 1828 (Fig. 8.14), forded the underground stream, and in one night explored more than $200 \mathrm{~m}$ of the cave. They were stopped by a cul-de-sac. In September, they were relieved by M. Schols, staff captain in the Belgian army, who mapped the known part of the cave (Schols 1832).

Several other researchers succeeded in dangerous explorations, namely Knight Hoy, general Niellon and Count de Cornelissen in 1834, and later on A. Delhasse in 1851 (Delhasse 1851), E.A. Martel, E. Van den Broeck and E. Rahir from 1898 to 1912 (Van den Broeck et al. 1910). More explorations opened new galleries from 1956 to 1959. A first dive in the upward sump opened the way to upward galleries, and more dives lengthened the cave, doubling the length of the underground stream, from $600 \mathrm{~m}$ to more than $1000 \mathrm{~m}$.

\subsubsection{The Researchers}

The Remouchamps cave has always fascinated palaeontologists and archaeologists. Van den Broeck (1902) studied Eocene shells, originating from the Paris basin, and certainly imported by cave dwellers as a necklace. Rahir (1920) discovered hundreds of flint tools, very small, later considered as epipaleolithic by Dewez (1974). 


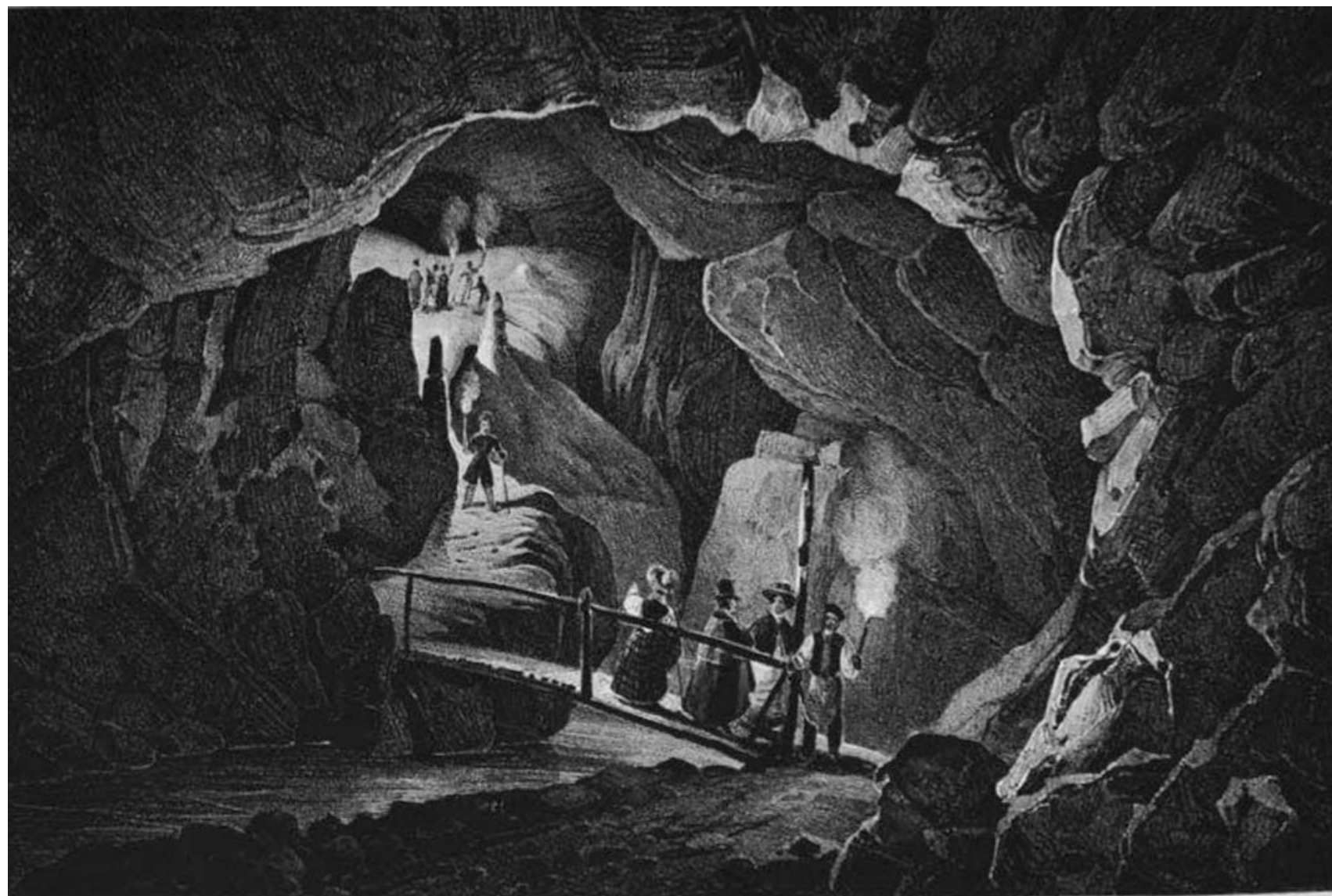

Fig. 8.14 The Remouchamps Cave: "Le Précipice”, engraving in Schols (1832)

The cave was carefully studied and described by Van den Broeck et al. (1910) in a very large book, "Les cavernes et les rivières souterraines de la Belgique", the bible of Belgian cavers and speleologists.

But it is mainly during the second half of the twentieth century that geomorphologists and geologists of the University of Liège devoted a lot of work to the cave, linking the levels of the cave with fluvial terraces of the Amblève (Ek 1961), mapping the geology of the cave (Ek 1970a) and analysing the influences of the geological structure on the cave morphology (Ek 1970b). In the 1980s, numerical ages and growth rate estimates were obtained for Late Pleistocene (Eemian) and Holocene speleothems (Gewelt 1985). Ek (1973) analysed waters of the underground river and seeping waters. Stream water analyses showed that stormy rains remove considerable amounts of dissolved calcium carbonate ( $>600 \mathrm{~kg}$ in $24 \mathrm{~h}$ in one analysed case), whereas moderate rains dissolve much less $(<0.5 \mathrm{~kg}$ in $24 \mathrm{~h}$ in another reported case) (Ek 1969).

The study of $\mathrm{CO}_{2}$ in the air above the underground stream showed that the river, coming from the remote upward passages and appearing in the show cave, degasses carbon dioxide very fast. Based on measurements made $30 \mathrm{~cm}$ above the water surface, the $\mathrm{CO}_{2}$ content of the air is of $\sim 6400 \mathrm{ppm}$, about 16 times the $\mathrm{CO}_{2}$ partial pressure in open air (Delecour et al. 1968).

Last but not least, the Walloon Commission for Study and Protection of Underground Cavities (C.W.E.P.S.S.) has mapped all karstic features of the basin, and the survey is under permanent updating, because of the activity of some swallow holes (De Broyer et al. 1996). From 1995 to 2005, the Public Service of Wallonia has ordered a geohazard assessment of karstic areas and, as such, Remouchamps is mapped at the scale of $1 / 10,000$.

\subsection{The Noû Bleû Cave and Its Drainage Area}

\subsubsection{The Syncline of Sprimont}

The geomorphological landscape of the eastern Condroz displays a succession of ridges and valleys aligned on the WSW-ENE structural grain of the Variscan basement. The ridges correspond to Upper Devonian sandstone anticlines and the valleys to Lower Carboniferous limestone synclines (see Chap. 2). Located $20 \mathrm{~km}$ south of Liège, the small town 

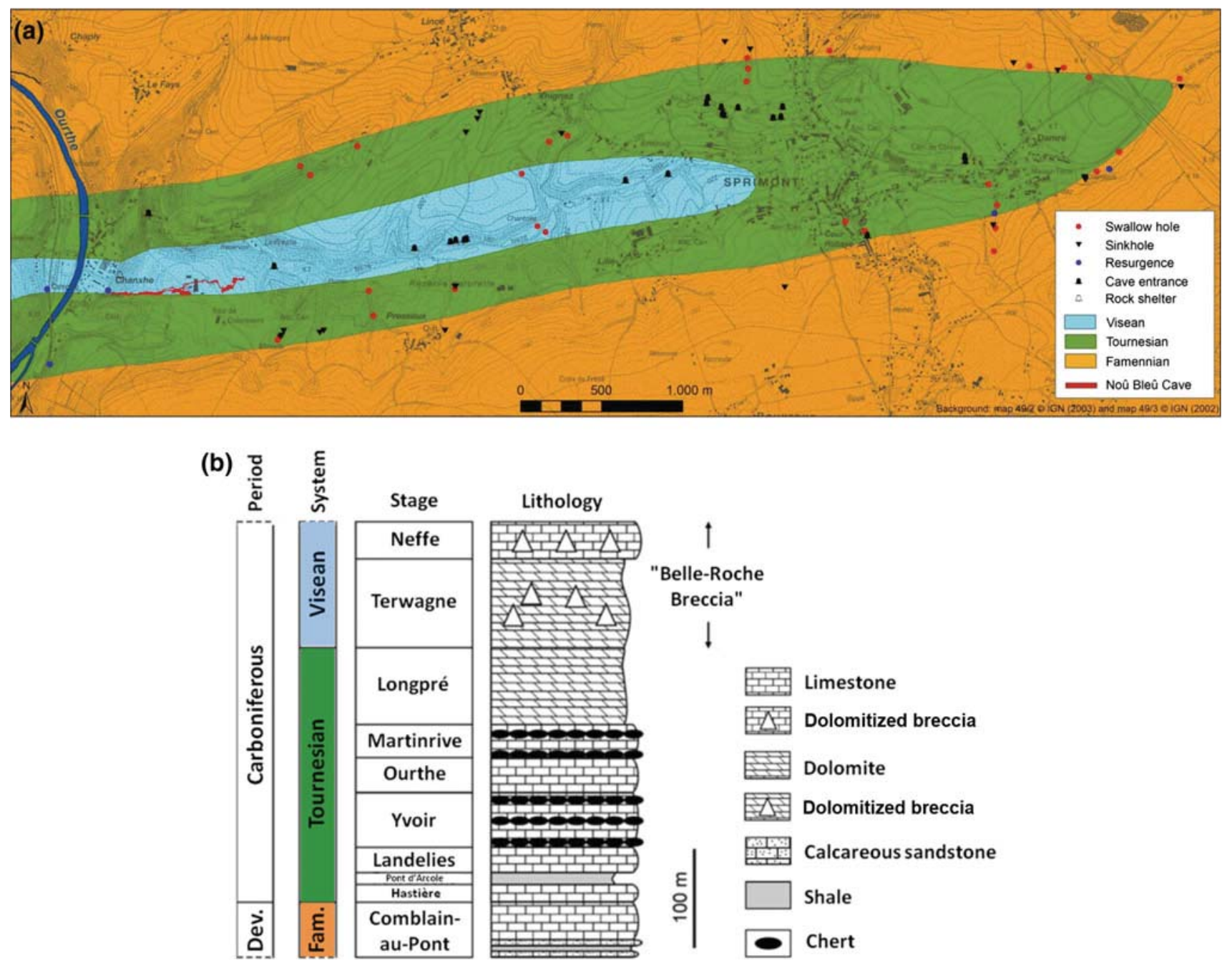

Fig. 8.15 a Karst phenomena and simplified lithostratigraphic map of the Sprimont Syncline (Geological data from the Geological map of Wallonia, Tavier-Esneux 49/1-2, by Bellière and Marion 2009, draft version, SPW-DGO3/ULg; Louveigné-Spa 49/3-4, by Mottequin and
Marion 2012, modified). b Simplified lithostratigraphic column of the Tournaisian and Visean series within the Sprimont Syncline. Dev Devonian; Fam Famennian (modified after Mottequin and Marion 2012)
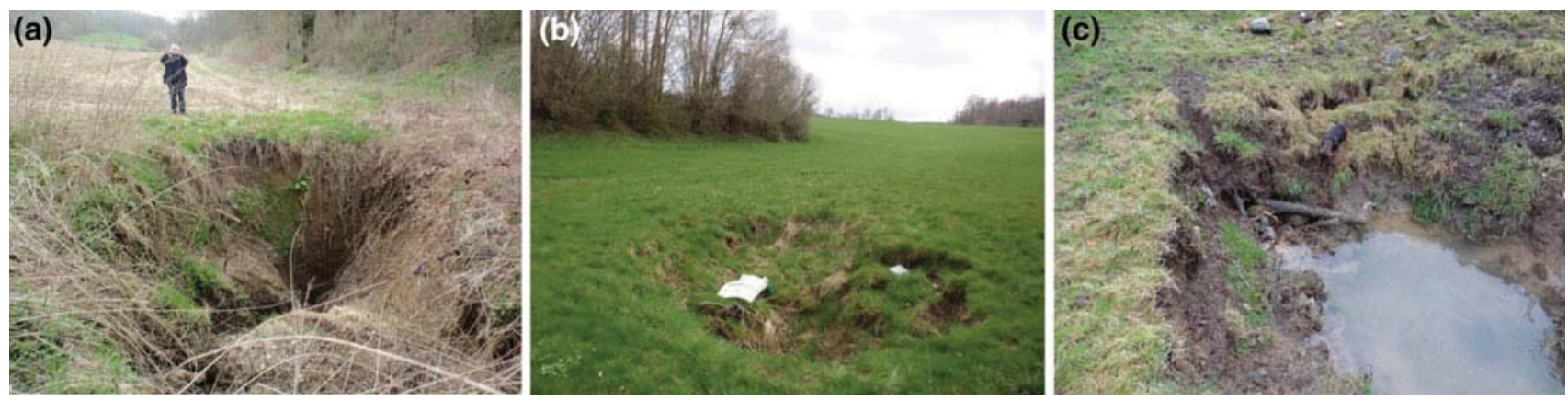

Fig. 8.16 a Dry swallow hole in the Sprimont Syncline (Photo A Peeters). b. 3 m diameter cover-collapse sinkhole in the Sprimont Syncline (Photo A Peeters). c Backfilled swallow hole in the Sprimont Syncline (Photo P Labarbe)

of Sprimont lies in such a typical limestone valley. The Syncline of Sprimont is cut transversally by the incised valley of the N-flowing Ourthe (Fig. 8.1). Its 1.2-km-wide, 8.4-km-long eastern part, in which the Noû Bleû karstic system is developed, stretches from Cornemont $(270 \mathrm{~m}$ asl) in the east to Chanxhe $(100 \mathrm{~m}$ asl $)$ in the west, where the 
valley joins the Ourthe. The entire catchment extends over $18 \mathrm{~km}^{2}$, including the sandstone crests, and is mostly covered by grassland and cropland, with small patches of forest on the steepest slopes and several, partly still active quarries.

\subsubsection{Geological Setting}

The Sprimont Syncline displays several lithostratigraphic units of the Tournaisian and Visean series. The Tournaisian is mainly characterized by carbonate sedimentation (crinoidal limestones, used as building stone under the name of 'Petit Granit') with subordinate shales (Poty et al. 2001; Mottequin and Marion 2012), (Fig. 8.15a, b). The Visean also features carbonate rocks, which are partly dolimitized and brecciated. The "Belle-Roche Breccia" originated in solution collapse of underlying evaporitic layers (Paproth et al. 1983). All these rocks are prone to karstic phenomena.

Moreover, Mottequin and Marion (2012) noted that some Upper Famennian calcareous sandstones of the syncline periphery may also be locally affected by karst phenomena, for instance in the eastern part of the valley (Fig. 8.15a, easternmost swallow hole).

The Sprimont Syncline is characterized by vertical to overturned beds on its south limb, while the north limb dip is $\sim 50^{\circ} \mathrm{S}$ (Mottequin and Marion 2012). This geometry plays an important role in the formation of underground galleries.

\subsubsection{Geomorphological Setting}

The Sprimont valley has an asymmetrical cross-profile, with steeper south-facing slopes, especially in its central stretch. As this asymmetry does not seem to be structurally controlled, it is hypothesized that it appeared during Pleistocene cold periods due to a different sensitivity of the two valley sides to periglacial slope processes. $\mathrm{N}-\mathrm{S}$ tributary valleys also display some asymmetry, with steeper west-facing slopes. In this case, it is classically attributed to the periglacial evolution of the valleys during cold periods, when east-facing lee slopes were especially affected by solifluction, which pushed the creek against the opposite valley side and progressively steepened it (Michel 1971).

Many small tributary streams running from the sandstone interfluves disappear underground into swallow holes halfway downslope, as soon as they flow over limestone. Frequently, two or three swallow holes are aligned in the same tributary valley, the most upstream one collecting the stream permanently and the others being active only under high flow conditions. As a consequence, the main valley has no thalweg and the downstream swallow holes are most often dry (Fig. 8.16a). The main valley long profile displays slope breaks, many of them related to the presence of swallow holes. Some of the swallow holes are cave entrances but more such entrances are also scattered over the higher slopes of the valley (Ek et al. 1997). In addition, the Sprimont valley is riddled with up to 10 -m-wide, 3-m-deep sinkholes, especially on the valley slopes, more rarely in the valley bottom and on the benches (Michel 1971). Most of them are cover-collapse sinkholes resulting in bowl-shaped depressions (Fig. 8.16b). Similar depressions observed in the tributary valleys are also produced by piping, more or less promoted by dissolution, occurring in the unconsolidated soil cover, whereby a cavity or a small conduit is developed upwards, due to progressive sediment removal by seepage water (Field 1999). Many of these sinkholes and swallow holes have been backfilled by the farmers in grassland and cropland (Fig. 8.16c).

In his description of the 16 caves so far identified in the Sprimont area, Briffoz $(1983,2012)$ highlighted four types of relationship between gallery morphology and geology: (I) galleries following the bedding planes (thus showing moderate and subvertical gradients in the northern and southern valley side, respectively), (II) galleries developed

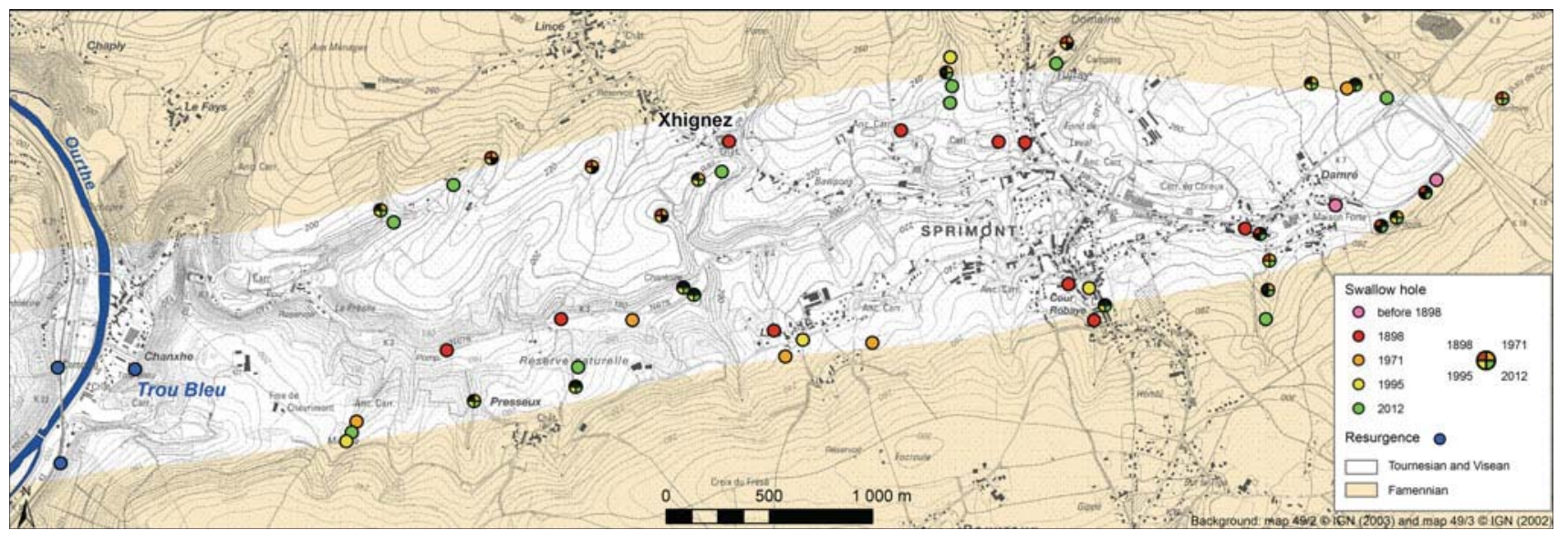

Fig. 8.17 Swallow hole dynamics in the Sprimont Syncline (from Peeters et al. 2012) 


\section{Longitudinal section}
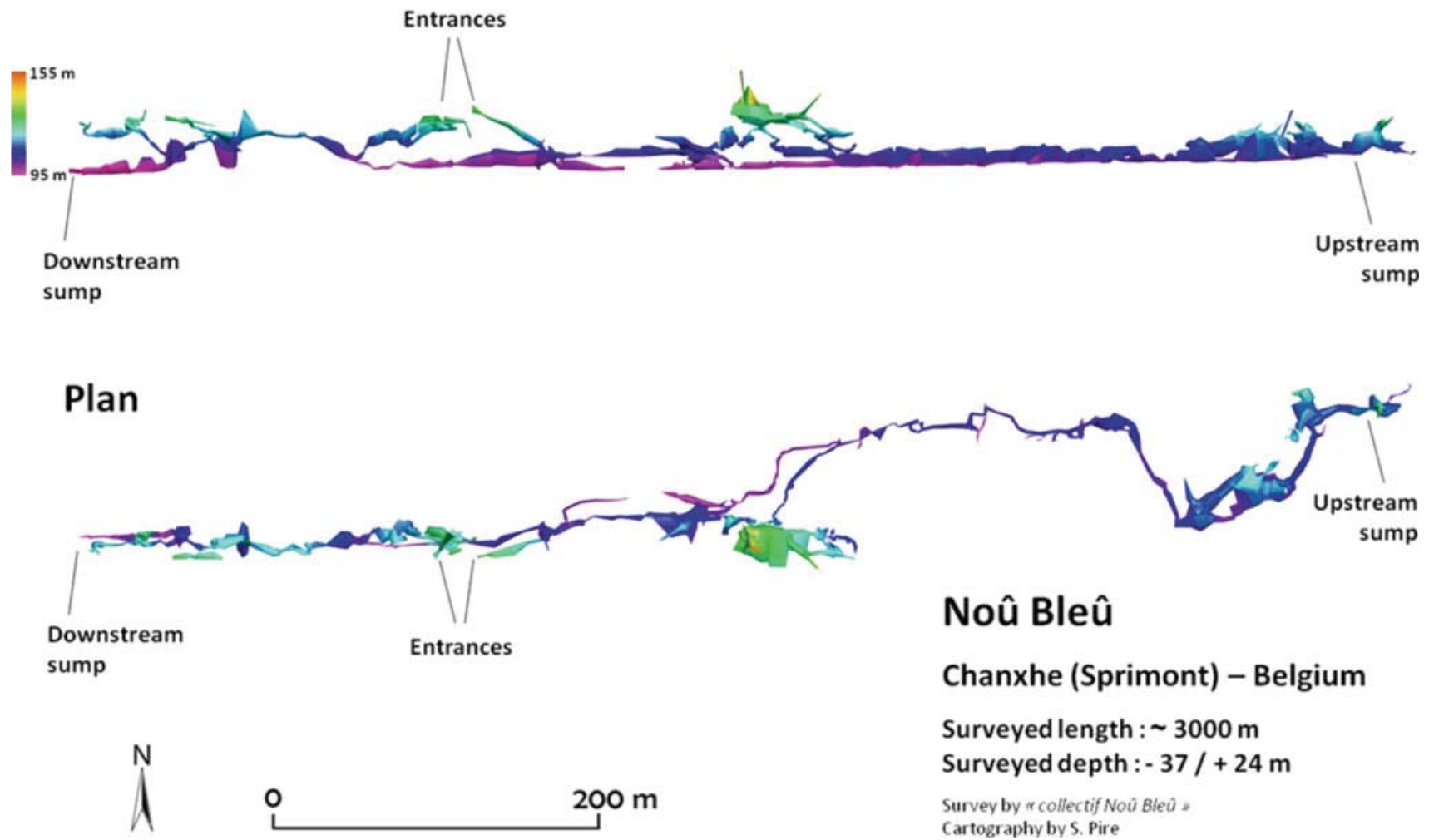

Fig. 8.18 The Noû Bleû Cave survey (April 2015)

along a joint (most pits of the northern valleyside) or (III) at joint intersection, and (IV) subhorizontal galleries with fluvial sediment. Groundwater flow patterns are typical in subhorizontal galleries whereas collapses are common in vertical galleries.

At the downstream end of the valley, outflow in the Ourthe of most waters of the Sprimont syncline occurs through the Trou Bleu resurgence located at the foot of the eastern valleyside of the Ourthe, although other resurgences might exist in the Ourthe riverbed (Ek et al. 1997), (Fig. 8.17). The Trou Bleu mean discharge is $\sim 0.23 \mathrm{~m}^{3} / \mathrm{s}$ (Meus et al. 2014).

\subsubsection{Karst Dynamics, from Quaternary to Present Day}

After solifluction deposits had filled the valleys and clogged the swallow holes during the Weichselian cold period, thus contributing to the interruption of every karstic process (Michel 1971), the Holocene reactivation of perennial runoff reopened some of the filled swallow holes. This dynamics is still going on, with new swallow holes opening upstream of the former ones. Inactive open swallow holes and their evolution were first described by Van Den Broek et al. (1910). Surveys of the valley bottoms (Michel 1971; Ek et al. 1997; Peeters et al. 2012) confirmed the upstream migration of swallow holes, eight of them opening in 72 years at an average distance of $270 \mathrm{~m}$ from their downstream predecessor (Fig. 8.17). As an example, the active swallow hole in the middle reach of the main valley moved $\sim 700 \mathrm{~m}$ upstream from 1898 to 1995 , at a mean rate of $6.7 \mathrm{~m} /$ year (Figs. 8.16a and 8.17). However, this natural process is often disrupted by human actions. For example, the Xhignez tributary stream was artificially diverted from its swallow hole in the early twentieth century, causing (re) activation of a downstream swallow hole in the 1950s, which in turn is now migrating upstream (Fig. 8.17).

\subsubsection{The Noû Bleû Cave}

After the main drain of the Sprimont Syncline had been the object of caving research since the 1960s (Briffoz 1983), an entrance leading to it was discovered in 2012 by the " $\mathrm{Club}$ de Recherches Spéléologiques Ourthe-Amblève" (CRSOA) in a large limestone quarry. The new cave has been called Nồ Blêu ('New Blue') in relation to the name Trou Bleu of its nearby resurgence. The cave has now been surveyed on more than $3000 \mathrm{~m}$ by the joint action of the CRSOA and geoscientists (Figs. 8.15a and 8.18). Two entrances open into the northern wall of the Chanxhe quarry. The depth, 


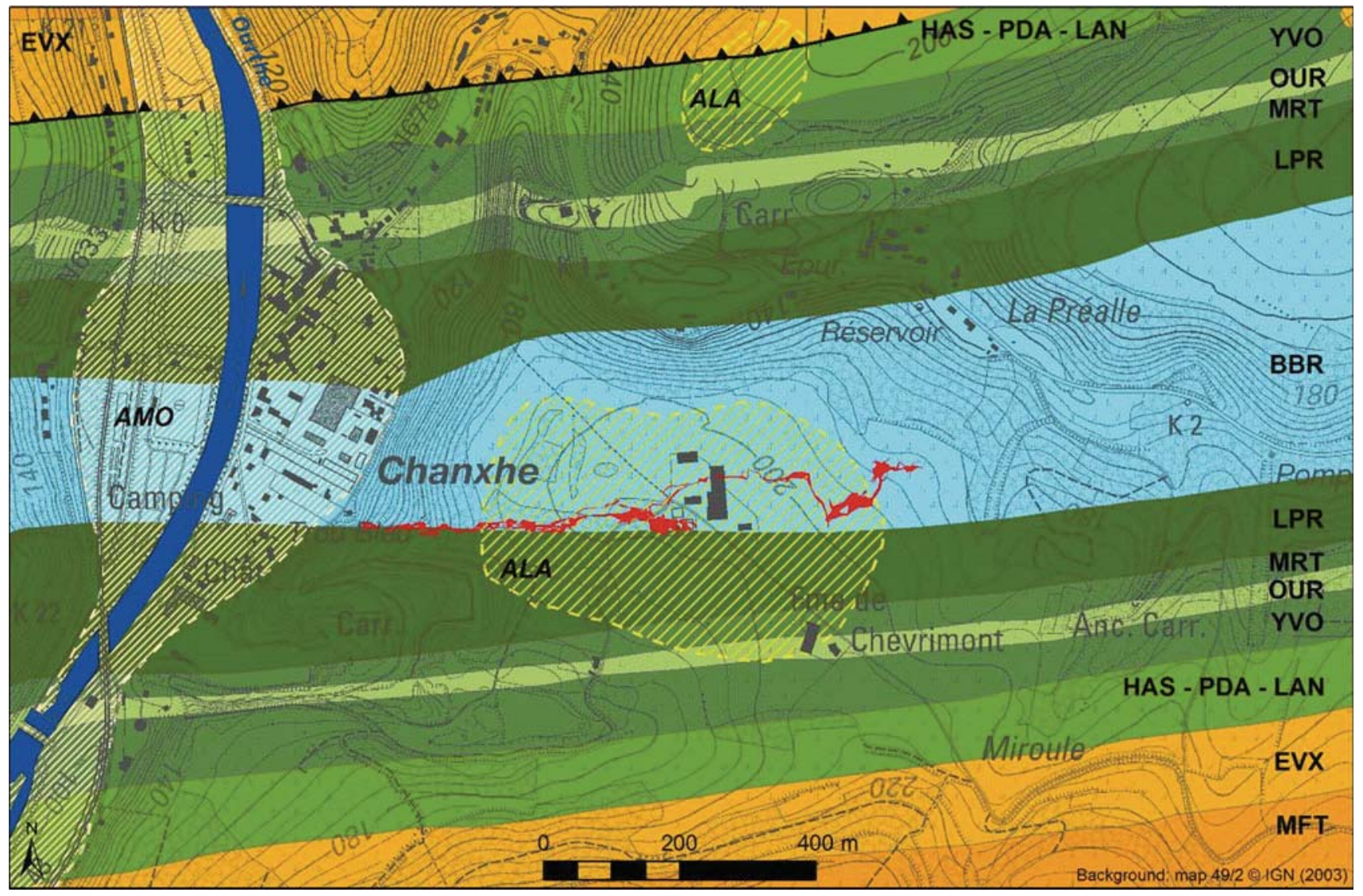

Fig. 8.19 The Noû Bleû Cave developed within the lithostratigraphic units of the Tournaisian and Visean series (Geological data from the Geological map of Wallonia, Tavier-Esneux 49/1-2, by Bellière and Marion 2009, draft version, SPW-DGO3/ULg convention). AMO

calculated from the eastern entrance, amounts to $37 \mathrm{~m}$ and a maximum height of $24 \mathrm{~m}$ has been measured at the level of a chimney. The 900-m-long active part of the cave, travelled by a stream, is limited by two sumps, the downstream one located at only $\sim 20 \mathrm{~m}$ from the Trou Bleu resurgence. The cave has also several dry upper levels taking the form of either subhorizontal galleries with fluvial sediment or large halls partly filled with collapsed boulders.

\subsubsection{Geological Setting}

Generally, the underground system follows the ENE-WSW axis of the syncline. The largest part of the cave extends in the "Belle-Roche Breccia" Formation (Fig. 8.19), whose limestone and dolomite boulders are particularly well exposed in the active galleries. The downstream half of the system closely follows the faulted contact with the more or less dolomitized Longpré limestones (Fig. 8.20).

The underground drainage is influenced by the geological structure. In the downstream half of the system, the main recent alluvium deposits; $A L A$ ancient alluvium deposits; $B B R$ "Belle-Roche Breccia" Fm; $L P R$ Longpré Fm; MRT Martinrive Fm; OUR Ourthe Fm; YVO Yvoir Fm; HAS-PDA-LAN Hastière-Pont d'Arcole_Landelies Fms; EVX Evieux Fm; MFT Monfort Fm)

drain itself more or less follows the faulted contact between the Longpré and "Belle-Roche Breccia" formations. The fault is observed in several places in the active galleries and the dry upper levels. By contrast, the upstream half of the system is entirely developed in the Belle-Roche breccia. Details of the karstic system are strongly controlled by the dolomitized and brecciated nature of the limestone and the density of secondary folds, faults and fractures. In places, the subvertical dip of the beds has led to the development of high galleries (Fig. 8.21a), while in other places subhorizontal bedding favoured the formation of large halls and roof collapses (Fig. 8.21b). The largest discovered hall is $40 \times 25 \mathrm{~m}$, with a maximum height of $15 \mathrm{~m}$.

\subsubsection{Active River-Run and Dry Upper Galleries}

Like Remouchamps, the Noû Bleû system is a water cave characterized by an active level and dry upper levels. Dissolution by the river has resulted in a varied morphology of the active level with alternating high and narrow 
Fig. 8.20 Entrances of the Noû Bleû Cave and fault separating the Longpré Formation from the "Belle-Roche Breccia" Formation (Photo A Peeters)

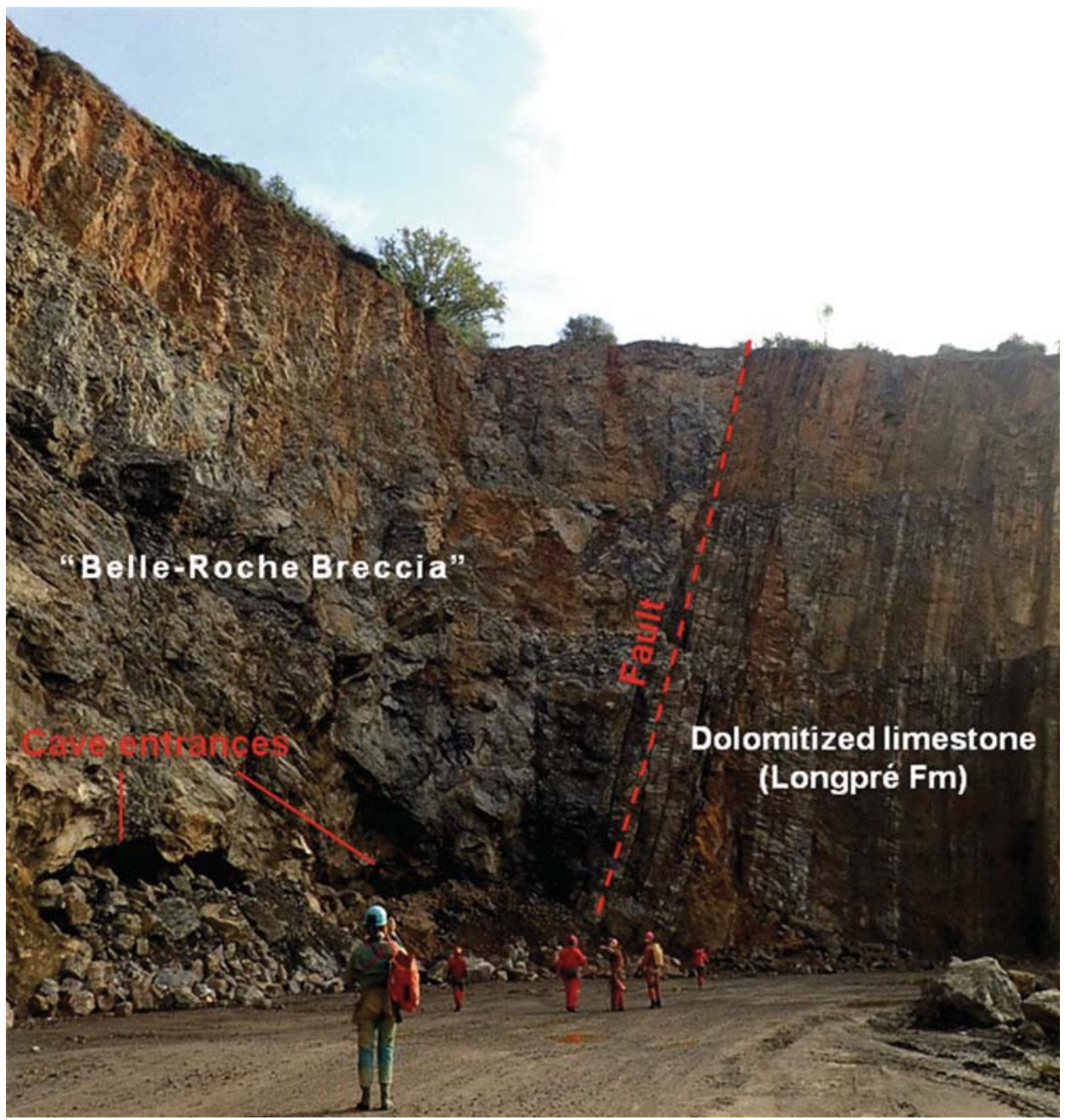

high-gradient reaches (Fig. 8.22a) and wider low-gradient reaches (Fig. 8.22b). The stream also runs through sumps and underneath boulders scattered across large halls.

The riverbed mostly exposes a sandy bedload. Likewise, some dry upper levels contain large quantities of sand derived from residues of the Oligocene marine sand cover still present in the watershed (Fig. 8.23a). Some river reaches are also characterized by coarser sediments, namely rounded pebbles including quartz and quartzite and coming from river terrace deposits located above the cave at $\sim 200 \mathrm{~m}$ asl (Fig. 8.19, ALA). These pebbles have been injected in the cave through soil piping failures in sinkholes and are now found in the stream at, and just downstream of, the plug injection places (Figs. 8.22b and 8.23b).

Among the dry upper levels, notches (Fig. 8.24) and fluvial sediment accumulation attest the action of an ancient underground river, particularly in galleries more than $8 \mathrm{~m}$ above the active level. Other upper levels display large halls partly filled with boulders attesting the predominance of gravitational processes.

\subsubsection{Speleothem Development}

The Noû Bleû is also characterized by its richness in speleothems of extremely diverse types, shapes and colours. Their type and shape diversity evidences that all speleothem-forming hydrologic mechanisms (through flowing, dripping, seeping, pooled and condensation water) were active in the cave (Hill and Forti 1997). Halls, walls and floors are frequently covered by flowstone sheets with various stalactites, stalagmites and columns (Fig. 8.25). Dripping effect is attested by delicate forms, such as fried egg stalagmites lying on a thin base of calcified sediment (Fig. 8.26a). The seeping mechanism is represented by helictites, which grow in every direction by capillarity water seeping through tiny internal canals, and by coralloid aragonite covering the walls (Fig. 8.26b). Rimstone dams of 
Fig. 8.21 a Dry upper level developed along subvertical beds in the Noû Bleû Cave (Photo G Rochez). $\boldsymbol{b}$ Large hall with roof collapse in the Noû Bleû Cave (Photo V Gerber)

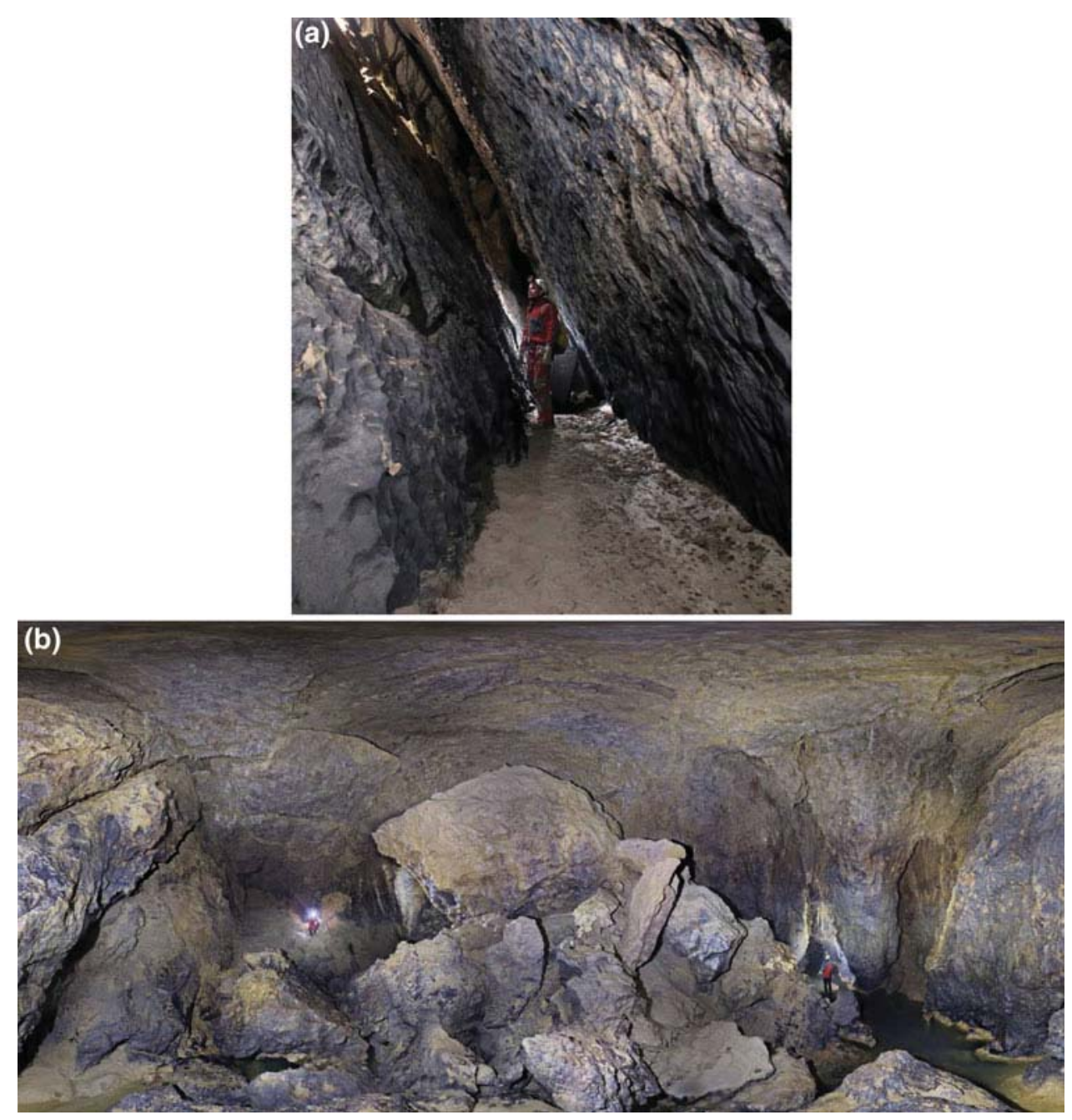

various size and shape are also common (Fig. 8.26c). Cave pearls were found within a shallow rim pool. Some speleothems may result from the combination of two or more mechanisms, like draperies, formed by water dripping and flowing (Fig. 8.26d). One anthodite, a fragile speleothem composed of aragonite needle clusters radiating outwards from the wall, has also been found (Fig. 8.26e). Finally, the large amount of fine sediment allowed the formation of conulites, i.e., hollow, cone-shaped speleothems that developed in deep conical depressions created in the sand by falling water. Figure $8.26 \mathrm{f}$ shows such conulites in their early stage of formation.

In order to preserve the environment and to maintain the speleothems in natural immaculate conditions, measures were taken from the beginning of the cave exploration. The installation of an appropriate mark-up was immediately set up to avoid damage and dirt. Highly fragile reaches are permanently closed while others are regularly cleaned.

\subsection{Human Involvements and Constraints}

The Remouchamps and Noû Bleû case studies allow one to highlight the human interaction with karst environments, not only in the sense of karst constraints for humans but also in that of karst as a resource that must be preserved (Ek 1985).

\subsubsection{Natural and Human-Induced Geohazards}

Karst represents multiple geohazards for man-made structures, which are moreover often accelerated or triggered by human actions. Dissolution of karst terrains may induce ground instability problems. For example, the Remouchamps viaduct, which carries a motorway across the Amblève valley, has seven piers which are founded at least partly on limestone. During the excavations for foundations in the late 1970s, the discovery of large open cavities led to 


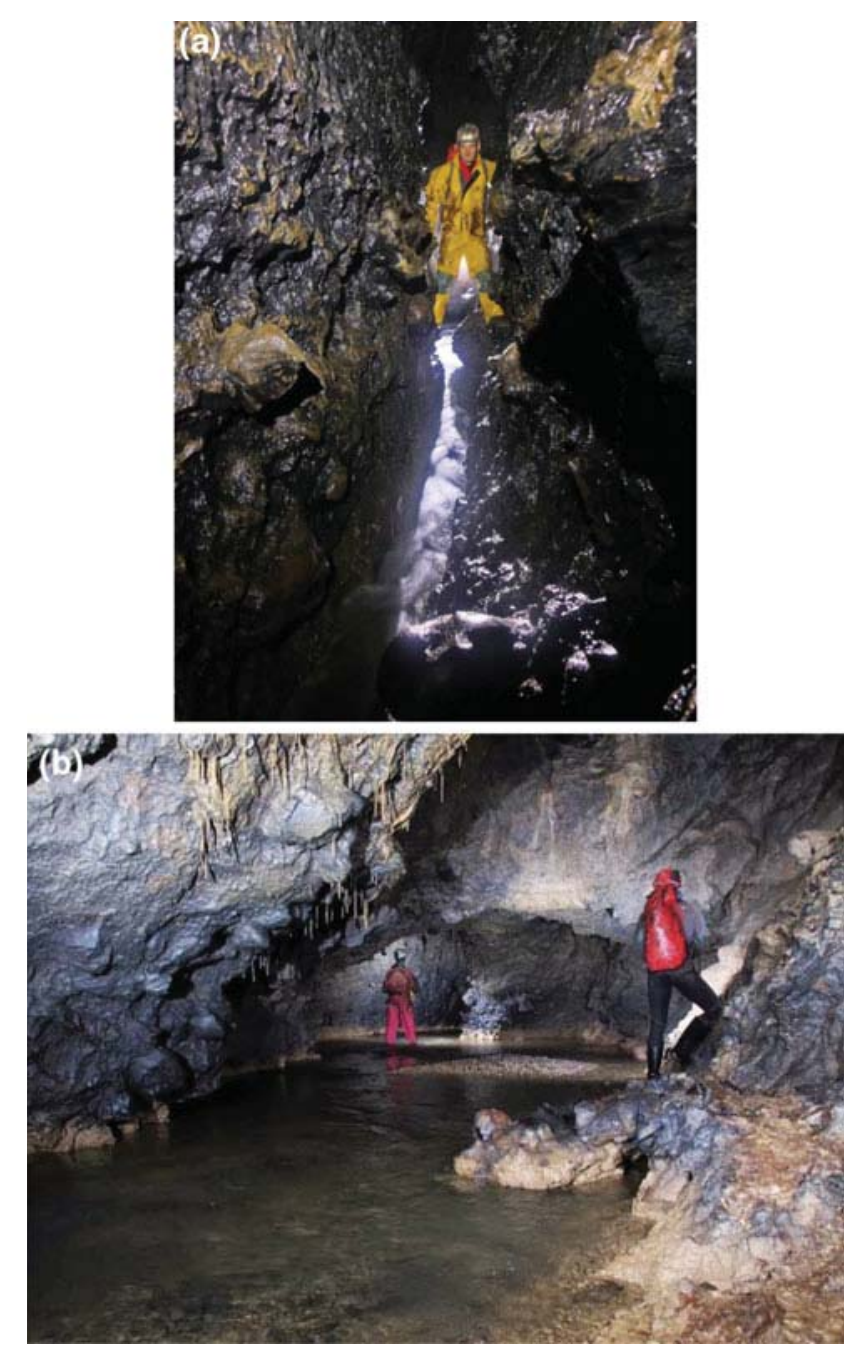

Fig. 8.22 a High gradient reach of the underground stream in the Noû Bleû Cave (Photo V Gerber). b Low gradient reach of the same stream (Photo G Rochez)

some redesign of the viaduct structure and an extra cost of $15 \%$ (Waltham et al. 1986). In the early 1980s, a parcelling project for several properties was established on the land extending over the Remouchamps cave. Based on precise topographic surveys, Ek (1983) demonstrated that the rock thickness was only $8 \mathrm{~m}$ between the ceiling of the Cathedral hall and the surface. The presence of faults increased the risk of instability due to roof collapse. The project was therefore abandoned.

Ground subsidence induced by the generation of sinkholes causes engineering and foundation problems. This underlines the need for a proper land use policy plan which would take into account the peculiarities of karst environments. That is why the Service Public de Wallonie (SPW) has compiled a digital karst dataset, which is used to delimit areas of subsidence susceptibility and help the decision makers to manage the land use policy. Mapping karst geohazards implies several issues to be dealt with, including the dynamics of karst. Indeed, the generation or reactivation of sinkholes and swallow holes is often favoured or triggered by human activity. The surveys conducted in the Sprimont syncline for over 100 years have clearly shown that natural process can be accelerated or triggered by the presence of diverted streams or broken water conduits (Peeters et al. 2012).

The presence of swallow holes can also lead to flood geohazards. During intense rainfall events, swallow holes can be blocked (e.g., clogged with logs and other debris), resulting in flooding of the blind valley, which can cause massive destruction of property (as for the Sinkhole Dale, see Fig. 8.4).

Karst aquifers are also extremely vulnerable to pollution due to the rapid transmission of groundwater and contaminants. Consequently, aquifer protection zones are delimited
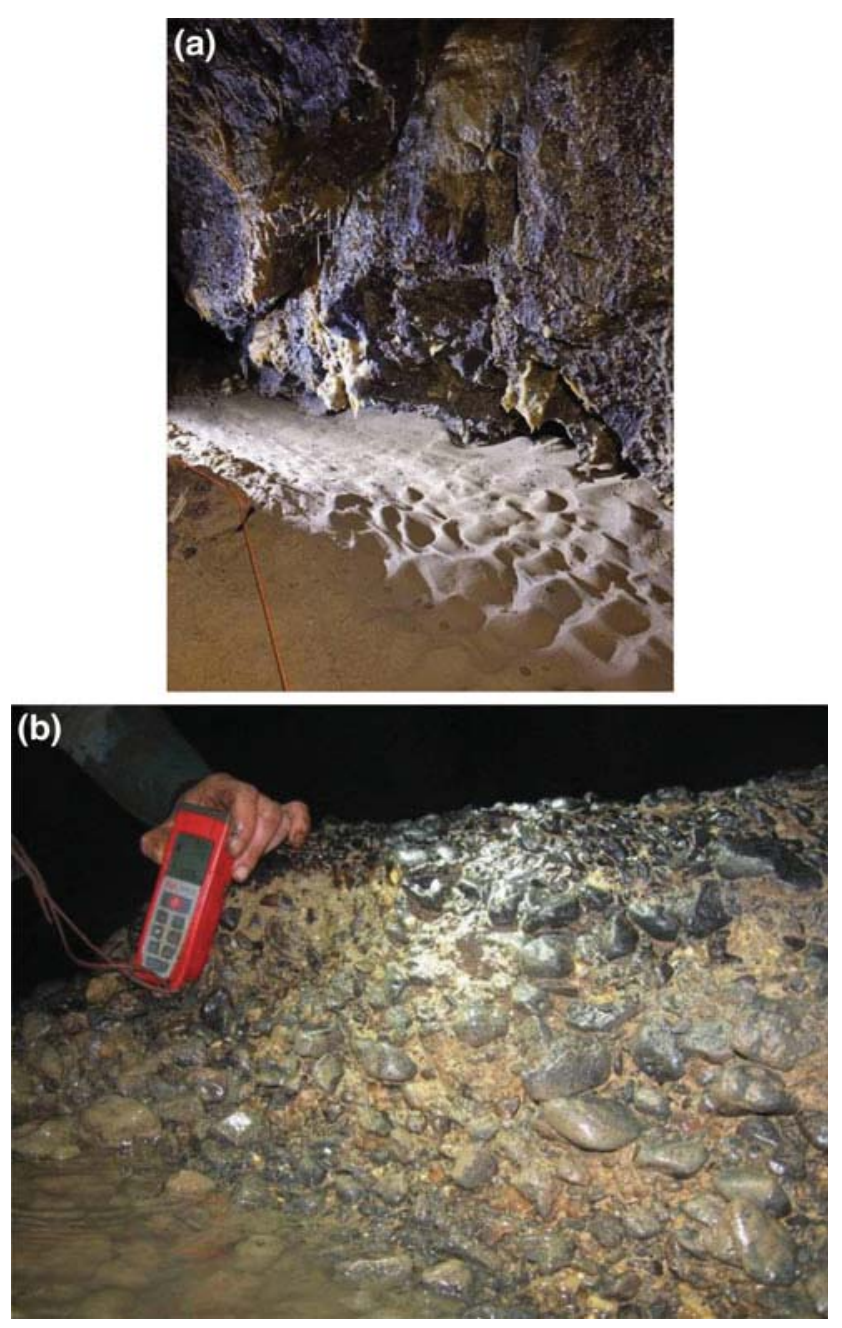

Fig. 8.23 Clastic deposits in the Noû Bleû Cave. a Sand deposit within a dry upper level (Photo V Gerber). b Rounded pebbles deposit in the underground stream (Photo JC London) 


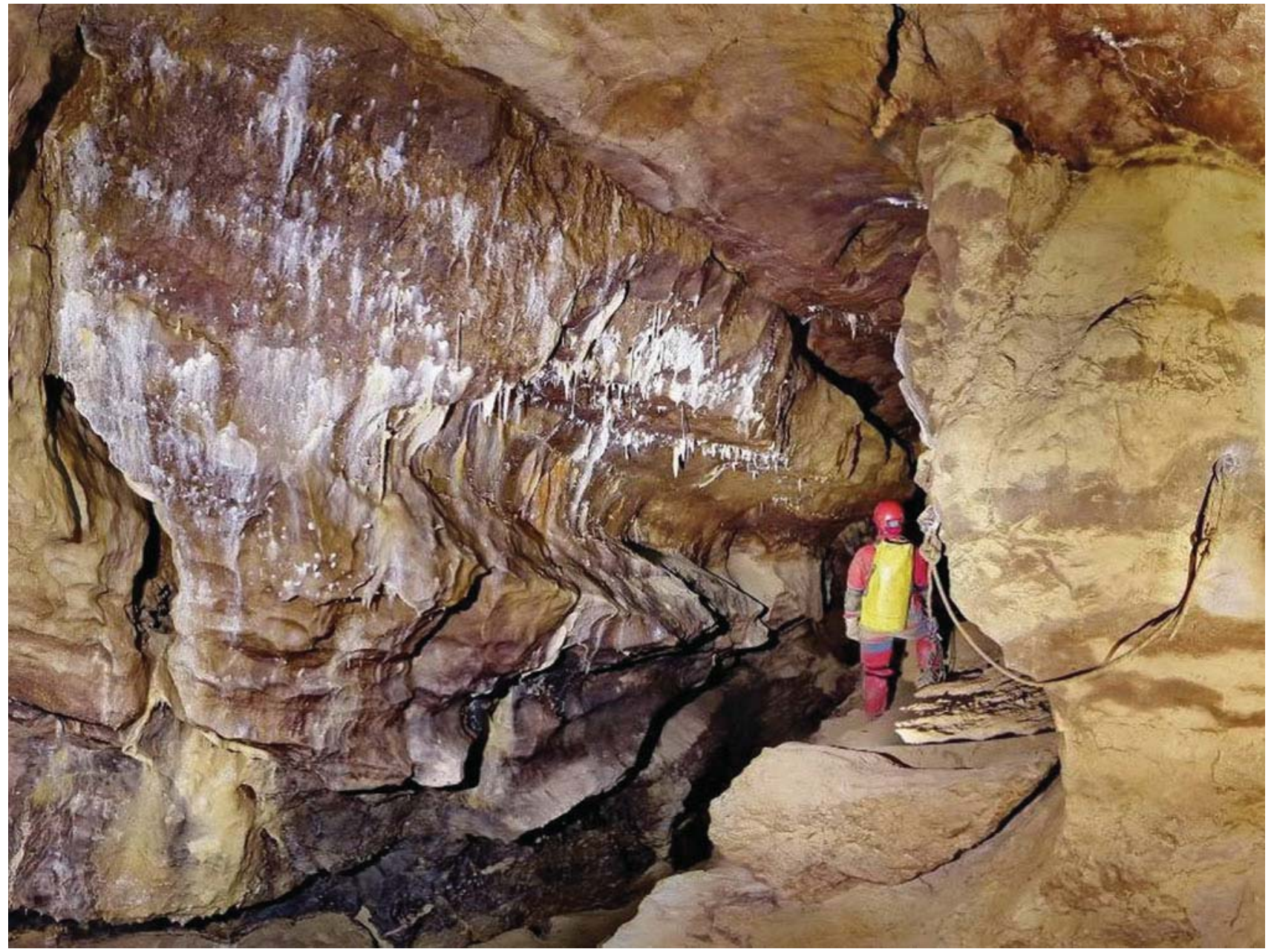

Fig. 8.24 Upper level ( $8 \mathrm{~m}$ above the underground stream) of the Noû Bleû Cave, with flat ceiling and notch on the walls (Photo V Gerber)

by the SPW to avoid spoiling sensitive karst ecosystems (SPW-DGO3 2014).

\subsubsection{Karst Environment, a Resource that Must Be Preserved}

Relations between karst environment and human activities are quite different for the two studied caves. The Remouchamps Cave, a commercial show cave, is the property of the local municipality and is rented by a private manager through a 25 -year lease. Staff is partly paid by tips and the some 100,000 tourists a year make the rent a good business for the municipality and the lessee. The long boat trip at the end of the visit is of course an important source of success. The business has its own souvenir shop and its own cafeteria and restaurant. The positive impact of tourism for the village retail traders and pubs is thus limited, although not negligible. Some stretches of the touristic part of the cave are vulnerable to light pollution, leading to the growth of undesirable lampenflora (Michel 2015). A complete renewal of the lighting is under way to reduce this excessive light pollution.

Officially, the whole cave is classified by the National Commission for Sites and Monuments. No major changes are thus theoretically allowed without permission of this Commission. The "wild" (non touristic) passages of the cavern are listed as "underground cavity of scientific interest" (De Broyer et al. 1996) and, as such, legally protected against pollution and damages. Nevertheless, some pollution of the underground river is caused by upward agricultural activities and camping.

Noû Bleû Cave is quite different. The cave opens in an active quarry and is not touristic at all. It is indeed still under exploration thanks to agreements with the owners and quarry operators. A large part of the cave, including its two 


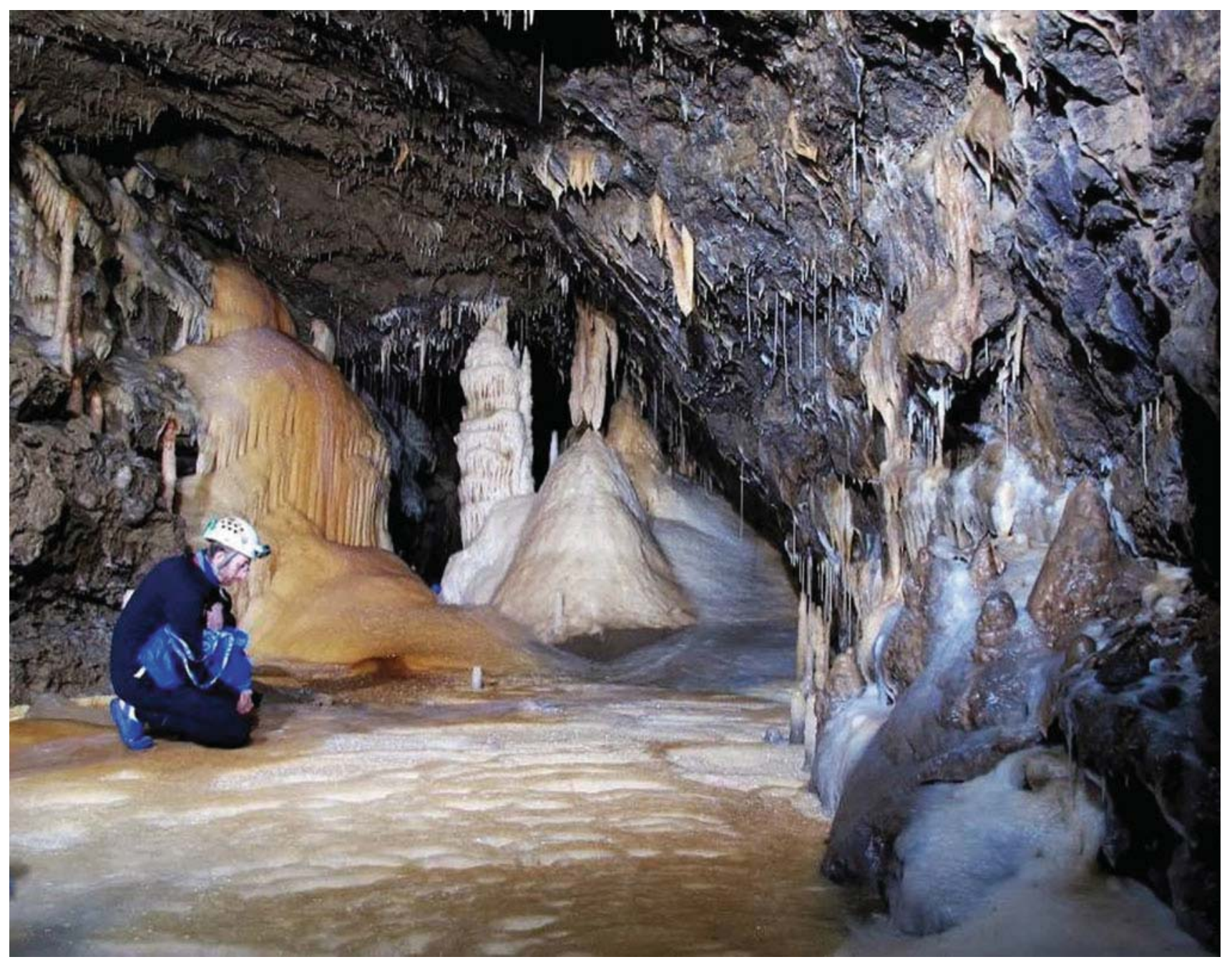

Fig. 8.25 Speleothem formation in "Les Cocognes" gallery (Photo G Rochez)

entrances, extends on properties belonging to the quarry owners. They could have decided to close the cave and prohibit its exploration. Instead, they decided to engage in constructive dialogue with the explorers, supported by the Sprimont municipality. Using the precise topographical survey of the cave, the quarry operators could define a buffer zone protection along the boundaries of the cave. On the other hand, the topographical surveys highlighted the danger of extracting rocks on this side of the quarry because it could provide a new outlet for the underground river, causing serious flooding problem within the quarry. Organizing visits of the cave for quarry operators and quarry-workers helped to raise awareness about the importance of preserving and protecting the karst environments. Similarly, conferences for the general public were organized by the explorers.

These two examples emphasize that karst environments are extremely vulnerable to pollution and degradation but on the other hand, they can represent an economical value in terms of touristic activities and extracting rocks.

\subsection{Conclusions}

The Sinkhole Dale, draining hard waters from Condroz on the west and aggressive waters from the Ardenne on the east, is a unique hydrological case in Belgium. There is no talweg in this valley and swallow holes and sinkholes collect the whole precipitation and divert it underground. A careful mapping of karstic geohazards is thus essential for the administration in charge of land use policy.

The Remouchamps Cave is for numerous tourists from Belgium and neighbouring countries a unique opportunity to discover the underground environment. Hence, a mission of awareness to nature is of great importance as a 

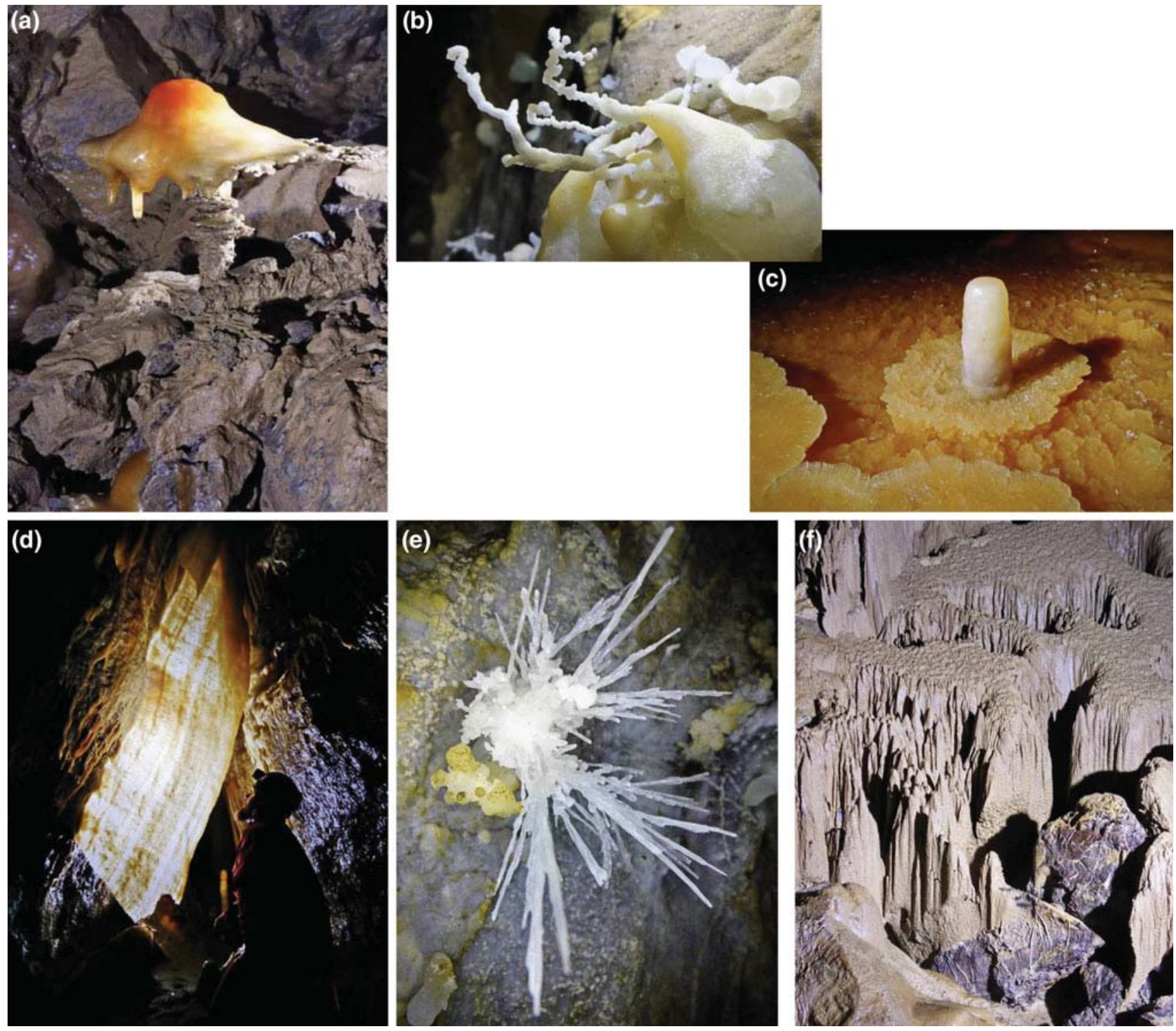

Fig. 8.26 Variety of the small-scale speleothem forms in the Noû Bleû Cave. a "Fried egg" stalagmite. b Coralloid aragonite. c Rim pools with candle-shaped stalagmite. d $2 \mathrm{~m}^{2}$ of drapery. e Anthodite aragonite. f Conulites in the early stage of formation (Photos V Gerber)

pedagogic project, and also a duty in order to preserve the natural treasures of the cave, notably by keeping the light to a minimum in view of preserving the speleothems.

The Sprimont Syncline is a very well documented case of karst dynamics. Four surveys in one century give an acute perception of movements of swallow holes and sinkholes. It also emphasizes that karst dynamics is often favoured or triggered by human activity.

The newly discovered Noû Bleû Cave leading to the resurgence of this basin has caused some trouble to the explorers because a large part of the cave, including its two entrances, lies in a private quarry. Fortunately, and this is rare in the history of cave exploration, constructive agreements could be reached between the public administration, the owners, the operators of the quarry and the explorers. The usefulness of the explorers was recognised for the sake of the quarry and the quarry-workers.

\section{References}

Bellière and Marion (2009) Geological map of Wallonia (Belgium), scale 1/10.000, sheet Tavier-Esneux 49/1-2 draft version, SPW-DGO3

Boulvain F, Pingot JL (2015) Genèse du sous-sol de la Wallonie. Académie royale de Belgique, Bruxelles, p 208

Boulvain F, Bultinck P, Coen M, Coen-Aubert M, Lacroix D, Laloux M, Casier J-G, Dejonghe L, Dumoulin V, Ghysel P, 
Godefroid J, Helsen S, Mouravieff NA, Sartenaer P, Tourneur F, Vangestaine M (1999) Les formations du Frasnien de la Belgique. Mem Geol Sur Belg 44:1-125

Bretz JH (1942) Vadose and phreatic features of limestone caverns. J Geol 50:675-811

Briffoz A (1983) Sprimont: le sous-sol régional à la loupe, Les cahiers de Spéléo Flash $\mathrm{N}^{\circ} 3$. Commission des publications de la Fédération spéléologique francophone de Belgique, Bruxelles

Briffoz A (2012) Descriptif du karst Sprimont-Chanxhe In: Livret-guide de l'excursion de la 16ème édition des Journées de Spéléologie scientifique, Centre belge de l'étude du Karst et Commission scientifique de l'Union belge de spéléologie, 8-9 Dec 2012

Coen M (1970) Stratigraphie du Frasnien de la grotte de Remouchamps. Ann la Soc géol Belg 93:73-79

Courtois H, Courtois J, Denoël R, Ek C (1969) Les explorations de la grotte de Remouchamps, notice historique. Parcs Nationaux 24: 19-29

Delecour F, Weissen F, Ek C (1968) An electrolytic field device for the titration of $\mathrm{CO}_{2}$ in air. Natl Speleol Soc Bull 30:131-136

De Broyer C, Thys G, Fairon J, Michel G, Vrolix M (1996) Atlas du Karst wallon, province de Liège, 3 vol. Commission wallonne d'Étude et de Protection des Sites souterrains, La Hulpe, p 896

Delhasse A (1851) La grotte de Remouchamps, près de Spa, avec notes historiques et orné d'une vue et d'un plan de la grotte. Bruxelles, p 114

Dewez M (1974) Nouvelles recherches à la grotte de Remouchamps. Bull Soc $r$ belge Anthropol Préhistoire 85:1-161

Ek C (1957) Les terrasses de l'Ourthe et de l'Amblève inférieures. Ann Soc Géol Belg 80:333-353

Ek C (1961) Conduits souterrains en relation avec les terrasses fluviales. Ann Soc Géol de Belg 84:313-340

Ek C (1969) Facteurs, processus et morphologie karstiques dans les calcaires paléozoïques de la Belgique, vol 3. Unpublished $\mathrm{PhD}$ thesis, Université de Liège

Ek C (1970a) Carte géologique de la grotte de Remouchamps (Belgique). Notice explicative. Ann Soc Géol Belg 93:287-292

Ek C (1970b) Les influences structurales sur la morphologie de la grotte de Remouchamps (Belgique). Ann Soc Géol Belg 93:293-304

Ek C (1973) Analyse d'eaux des calcaires paléozoïques de la Belgique. Serv Géol Belgique, Prof Pap 18:1-33

Ek C (1974a) Le cadre géologique et géomorphologique In: Nouvelles Recherches à la Grotte de Remouchamps. Bull Soc R Belge Anthropol Préhistoire 85:7-15

Ek C (1974b) Étude sédimentologique dans la Grotte de Remouchamps (avec la collaboration de S. Alexandre-Pyre et E. Juvigné) In: Nouvelles recherches à la grotte de remouchamps. Bull Soc R Belge Anthropol Préhistoire 85:16-41

Ek C (1983) L'eau dans le Vallon des Chantoirs (Remouchamps). Une leçon sur les collaborations nécessaires. La prot Eaux karstiques. Hydrographica 1-2:7-14

Ek C (1985) De la connaissance du milieu karstique à sa gestion. Ann Soc Géol Belg 108:303-304

Ek C (1995) Grottes et rivières des régions calcaires In: Demoulin A (éd) L'Ardenne, Essai de Géographie physique, pp 178-193

Ek C, Michel R, Mousny V, Closson D (1997) The dynamics of the karstic features of Sprimont (Belgium) and its consequences on the land-use planning. In: Proceedings of the 12th International Congress of Speleology, vol 5. Switzerland, pp 13-14

Field MS (ed) (1999) A lexicon of cave and karst terminology with special reference to environmental karst hydrology. Report
EPA/600/R-99/006. U.S. Environmental Protection Agency, Washington, DC, p 195

Gewelt M (1985) Cinétique du concrétionnement dans quelques grottes belges: apport des datations $14 \mathrm{C}$ et $230 \mathrm{Th} / 234 \mathrm{U}$. Ann Soc Géol Belg 108:267-273

Hill CA, Forti P (eds) (1997) Cave minerals of the world, 2nd edn. Natl Speleol Soc, Huntsville, AL, p 463

Juvigné E, Gewelt M (1988) Téphra et dépôts des grottes: intérêt stratigraphique réciproque. Ann Soc Géol Belg 111:135-140

Meus P, Moureaux P, Gailliez S, Flament J, Delloye F, Nix P (2014) In situ monitoring of karst springs in Wallonia (Southern Belgium). Environ Earth Sci 71(2):533-541. doi:10.1007/s12665-013-2760-x

Michel G (2015) Les enjeux d'une exploitation touristique durable. Remouchamps: perle de l'Amblève ou jungle souterraine? Ecokarst 100:10-11

Michel R (1971) Le Vallon de Sprimont à Chanxhe. Unpublished Ms thesis, université de Liège, p 163

Mottequin B, Marion JM (2012) Lithostratigraphie du Tournaisien et du Viséen (Carbonifère) dans le synclinal de Chanxhe-Sprimont (province de Liège, Belgique) In: Livret-guide de l'excursion de la 16ème édition des Journées de Spéléologie Scientifique, Centre belge de l'étude du Karst et Commission scientifique de l'Union belge de Spéléologie, 8-9 Dec 2012

Paproth E et al (1983) Bio- and Litho-stratigraphic subdivisions of the Dinantian in Belgium, a review. Ann Soc Géol Belg 106:185-239

Peeters A, Ek C, Labarbe P \& Michel R (2012) La dynamique du karst dans le synclinal de Sprimont de 1898 à 2012. In: Livret-guide de l'excursion de la 16ème édition des Journées de Spéléologie Scientifique, Centre belge de l'étude du Karst et Commission Scientifique de l'Union belge de spéléologie, 8-9 Dec 2012

Pissart A, Van Vliet-Lanoë B, Ek C, Juvigné E (1988) Des traces de glace de ségrégation dans la grotte de Remouchamps (Belgique). Conséquences en ce qui concerne la sédimentation et la paléoclimatologie. Ann Soc Géol Belg 111:125-133

Poty E, Hance L, Lees A, Hennebert M (2001) Dinantian lithostratigraphic units (Belgium). In: Bultynck P, Dejonghe L (eds) Guide to a rivised lithostratigraphic scale of Belgium. Geol Belg 4:69-94

Rahir E (1920) L'habitat tardenoisien des grottes de Remouchamps, Châleux et Montaigle. Bull Soc Anthropol Brux 35:31-89

Rixhon G, Demoulin A (2010) Fluvial terraces of the Amblève: a marker of the Quaternary river incision in the NE Ardennes massif (Western Europe). Z für Geomorphol 54(2):161-180. doi:10.1127/ 0372-8854/2010/0054-0008

Schols M (1832) Description de la grotte de Remouchamps, située à deux lieues à l'ouest de Spa. Bruxelles, p 8, one plan, 8 engravings SPW-DGO3 (2014) État des nappes d'eau souterraine de Wallonie. Service public de Wallonie, DGO 3 (DGARNE), Belgique. Dépôt légal D/2014/11802/11-ISBN 978-2-8056-0142-2

Van den Broeck E (1902) Quelques mots à propos des nouvelles fouilles exécutées dans la grotte de Remouchamps. Bull Soc Anthropol Brux 21:35-44

Van den Broeck E, Martel EA, Rahir E (1910) Les cavernes et les rivières souterraines de Belgique, Bruxelles, 2 vol, p $1592+92+$ LXVI

Waltham AC, Vandenven G, Ek C (1986) Site investigation on cavernous limestone for the Remouchamps Viaduct, Belgium. Ground Eng 19(8):16-18

Weninger B, Jöris $\mathrm{O}(2008) \mathrm{A}{ }^{14} \mathrm{C}$ calibration curve for the last $60 \mathrm{ka}$ : the Greenland-Hulu U/Th timescale and its impact on understanding the Middle to Upper Paleolithic transition in Western Eurasia. J Hum Evol 55:772-781 